\title{
Electrospun Poly(ethylene Terephthalate)/Silk Fibroin Composite for Filtration Application
}

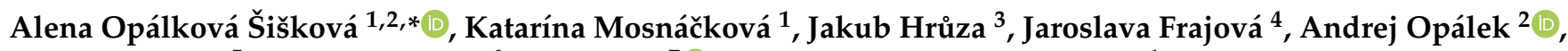 \\ Mária Bučková ${ }^{5}$, Katarína Kozics ${ }^{6}$, Petra Peer ${ }^{7}$ (D) and Anita Eckstein Andicsová 1,* \\ 1 Polymer Institute of Slovak Academy of Sciences, Dúbravská cesta 9, 84541 Bratislava, Slovakia; \\ katarina.mosnackova@savba.sk \\ 2 Institute of Materials and Machine Mechanics, Slovak Academy of Sciences, Dúbravská cesta 9, \\ 84513 Bratislava, Slovakia; andrej.opalek@savba.sk \\ 3 Advanced Technologies and Innovation, Institute for Nanomaterials, Technical University in Liberec, \\ Studentská 1402/2, 46117 Liberec, Czech Republic; jakubhruza1@seznam.cz \\ 4 Faculty of Arts and Architecture, Technical University in Liberec, Studentská 1402/2, \\ 46001 Liberec, Czech Republic; jaroslava.frajova@tul.cz \\ 5 Institute of Molecular Biology, Slovak Academy of Sciences, Dúbravská cesta 9, 84551 Bratislava, Slovakia; \\ maria.buckova@savba.sk \\ 6 Cancer Research Institute, Biomedical Research Center, Slovak Academy of Sciences, Dúbravská cesta 9 , \\ 84505 Bratislava, Slovakia; katarina.kozics@savba.sk \\ 7 Institute of Hydrodynamics of the Czech Academy of Sciences, v. v. i., Pod Patankou 5, \\ 16612 Prague 6, Czech Republic; peer@ih.cas.cz \\ * Correspondence: alena.siskova@savba.sk (A.O.S.); anita.andicsova@savba.sk (A.E.A.)
}

Citation: Opálková Šišková, A.; Mosnáčková, K.; Hrůza, J.; Frajová, J.; Opálek, A.; Bučková, M.; Kozics, K.; Peer, P.; Eckstein Andicsová, A. Electrospun Poly(ethylene Terephthalate)/Silk Fibroin Composite for Filtration Application. Polymers 2021, 13, 2499. https:// doi.org/10.3390/polym13152499

Academic Editor: Andrea Ehrmann

Received: 30 June 2021

Accepted: 27 July 2021

Published: 29 July 2021

Publisher's Note: MDPI stays neutral with regard to jurisdictional claims in published maps and institutional affiliations.

Copyright: (c) 2021 by the authors. Licensee MDPI, Basel, Switzerland. This article is an open access article distributed under the terms and conditions of the Creative Commons Attribution (CC BY) license (https:// creativecommons.org/licenses/by/ $4.0 /)$.
Abstract: In this study, fibrous membranes from recycled-poly(ethylene terephthalate)/silk fibroin (r-PSF) were prepared by electrospinning for filtration applications. The effect of silk fibroin on morphology, fibers diameters, pores size, wettability, chemical structure, thermo-mechanical properties, filtration efficiency, filtration performance, and comfort properties such as air and water vapor permeability was investigated. The filtration efficiency $(\mathrm{FE})$ and quality factor $\left(\mathrm{Q}_{\mathrm{f}}\right)$, which represents filtration performance, were calculated from penetration through the membranes using aerosol particles ranging from $120 \mathrm{~nm}$ to $2.46 \mu \mathrm{m}$. The fiber diameter influenced both FE and $Q_{f}$. However, the basis weight of the membranes has an effect, especially on the FE. The prepared membranes were classified according to EN149, and the most effective was assigned to the class FFP1 and according to EN1822 to the class H13. The impact of silk fibroin on the air permeability was assessed. Furthermore, the antibacterial activity against bacteria $S$. aureus and E. coli and biocompatibility were evaluated. It is discussed that antibacterial activity depends not only on the type of used materials but also on fibrous membranes' surface wettability. In vitro biocompatibility of the selected samples was studied, and it was proven to be of the non-cytotoxic effect of the keratinocytes (HaCaT) after $48 \mathrm{~h}$ of incubation.

Keywords: poly(ethylene terephthalate); silk fibroin; electrospun membrane; air filtration; antibacterial activity; comfort properties

\section{Introduction}

Following the current pandemic situation worldwide and prognosis published up to date by World Health Organization (WHO), there is no doubt that polymer fibrous membranes like filters or masks against COVID-19 are currently one of the most demanded products ever [1-3]. With this respect, every alternative and fabrication method should be seriously considered [4-7].

Electrospinning belongs among the most attractive methods for fabricating the fibrous membranes, which is a facile and effective approach for forming fine fibers in the microup to nanometers scale under the application of electric field [8]. Furthermore, this method 
offered the possibility to also prepare fibrous polymer products from synthetic or natural polymers or virgin and recycled polymers (plastic wastes) [9-11].

Electrospun products have already been studied for many applications such as wound healing [12,13], tissue engineering [14,15], drug-releasing and drug target delivery systems $[16,17]$, sensors [18,19], membranes [20,21], batteries [22,23], solar cells [24,25], catalysts [26,27], protecting clothing [28,29], separation [30], decommissioning [31], and environmental remediation [32]. However, the randomly arranged ultrafine fibers in the electrospun membranes, the high surface area to volume ratios, nano-porosity, good mechanical properties, and vapor permeability of such membranes pre-destined them for filtration membranes and especially for personal protection as face masks against very fine dirt and bacteria, but also viruses with dimensions of about $100 \mathrm{~nm}$ [33-36].

Different polymeric materials have been used for producing electrospun membrane for filtration including cellulose acetate (CA) [37], silk fibroin (SF) [38], poly(lactic acid) (PLA) [39], polyamide-6 (PA6), poly(vinyl alcohol) (PVA) [40], polyvinylacetate (PVAc) [37], polyacrylonitrile (PAN) [41,42], polyvinylidene fluoride (PVDF) [43], or poly(ethylene terephthalate) (PET) [33,44].

It has already been published that the filtration efficiency of electrospun membranes could be high, even very close to $100 \%$. However, the efficiency depends on the basis weight of the electrospun non-woven textile, the diameter of fibers in the membrane, and porosity [45]. Moreover, pressure drop and air or water vapor permeability are significant parameters for assessing filtration media properties relating to user comfort in personal protection applications [46]. Therefore, it is always challenging to increase efficiency while meanwhile maintaining low pressure drops.

However, according to the latest statistics, PET accounts for $5 \%$ of the total annual production of plastics. It is up to 18.2 million tons, eventually ending up in landfills or incinerators [47]. Of this, only about $20 \%$ is used for recycling. Poly(ethylene terephthalate) is the standard thermoplastic polyester [48], which has excellent mechanical, thermal, and chemical properties and good dimensional stability. It is highly flexible, semi-crystalline, and shows excellent electrical insulating properties and high strength [49]. Poly(ethylene terephthalate) is the most common polymer for food and beverage packaging [50,51]; however, it can be seen in applications as automotive [49] or even medicine [52].

On the contrary, silk fibroin (SF) is obtained from natural silk cocoons type Bombyx mori. It is favorable due to its unique properties, including biocompatibility, biodegradability, minimal inflammatory reactions, and water vapor, as well as oxygen permeability $[53,54]$. The blending of silk fibroin, in combination with PET, is a novel approach that can use plastic waste and recover it for a new product with added value. By adding the silk, it is considered to give the better user comfort properties such as air and water vapor permeability to the composite membrane. Good air and water vapor permeability of electrospun silk fibroin mats has been already reported by many authors [55-57].

The main objective of the study is getting a membrane that will have good user comfort properties while mechanical properties are maintained.

In the present study, the electrospun membranes containing PET from bottle waste with varying contents of silk fibroin, according to the author's best knowledge for the first time, were investigated. The composite membranes were characterized thoroughly. Scanning electron microscopy (SEM) was used for observing morphology, wettability of membranes was tested by measuring of water contact angle, the chemical composition was confirmed by attenuated total reflectance-Fourier transforms infrared spectrometry (ATR-FTIR), mechanical and thermal properties were investigated by dynamic mechanical thermal analysis (DMTA) and thermogravimetric analysis (TGA), respectively. This study's main objective was to prepare the filtration medium with the ambition to serve as personal protection against fine dirt, bacteria, or even viruses with convenient user comfort properties. Therefore, the filtration efficiency, air, and water vapor permeability were tested. In the end, the antibacterial activity and biocompatibility were determined. 


\section{Materials and Methods}

\subsection{Materials}

Commercially degummed silk fiber from Bombyx mori (Zhejiang, China) was used for our experiments. The municipal waste available beverages bottle was used as a source of poly(ethylene terephthalate) (r-PET) with the molar mass $M_{w}=4.4 \times 10^{4} \mathrm{~g} \cdot \mathrm{mol}^{-1}$ and molar-mass dispersity $\bigoplus_{M}=1.42$. The molar mass measurement has already been described in our previous work [33]; 1,1,1,3,3,3-hexafluoro-2-propanol (HFIP, >99.0\% purity) was purchased from TCI Tokyo Kasei (Tokyo, Japan). Dichloromethane p.a. (DCM, 99.8\% purity) was purchased from Lach-Ner (Bratislava, Slovakia). Phosphate Buffer Saline (PBS) was purchased from Sigma-Aldrich (Weiheim, Germany) and absolute ethanol SOLVANAL, 99.8\% from Centralchem (Bratislava, Slovakia). Di-ethylhexyl-sebacate (DEHS, >97.0\% purity) was purchased from Palas $\mathrm{GmbH}$ (Karlsruhe, Germany). Casein-peptone lecithin polysorbate broth (CPLP broth) (base) was purchased from Merck, Burlington, MA, USA. Gram-positive bacteria Staphylococcus aureus (CCM 4223) and the Gram-negative bacteria Escherichia coli (CCM 3954) were purchased from the Czech Collection of Microorganisms, Masaryk University (Brno, Czech Republic). The human keratinocyte cell line HaCaT (T0020001) was purchased from AddexBio (San Diego, USA). Dulbecco's Modified Eagle Medium (DMEM), fetal calf serum (FCS), and antibiotics (penicillin $100 \mathrm{U} / \mathrm{mL}$; streptomycin $100 \mu \mathrm{g} / \mathrm{mL}$ ) were purchased from Gibco BRL (Paisley, UK). 3-(4,5-Dimethyldiazol-2-yl)2,5-diphenyltetrazolium bromide (MTT) was purchased from Calbiochem (Merck Millipore, Darmstadt, Germany).

\subsection{Methods}

\subsubsection{Preparation of Polymer Solutions for Electrospinning}

(a) The r-PET solution was prepared in concentrations $10 \%(\mathrm{~m} / \mathrm{V})$ in the blend of 1,1,1,3,3,3-hexafluoro-2-propanol (HFIP) and dichloromethane (DCM). Pieces of postconsumer PET bottle were weighted into the vials, and the solvent HFIP was added into the vial. The solution was stirring intensively on magnetic plate EKA with an intensity of $750 \mathrm{rpm}$ for $3 \mathrm{~h}$. After dissolving in HFIP, the DCM was added to reach the required concentrations. The final solvent ratio in the solution was 30/70\% $V / V$ HFIP/DCM.

(b) A total of $2 \mathrm{~g}$ of silk fibers wer dissolved in $10 \mathrm{~mL}$ of a $9.3 \mathrm{M}$ lithium bromide solution by stirring for $4 \mathrm{~h}$ at $60{ }^{\circ} \mathrm{C}$ to obtain a $20 \%(\mathrm{~m} / \mathrm{V})$ solution. The homogeneous solution was dialyzed for 2 days in distilled water using the dialysis membrane (12-14 kDa, Sigma-Aldrich, Saint Louis, MO, USA). The aggregates that occurred during dialysis were removed by centrifugation $\left(10 \mathrm{~min}, 10,000 \mathrm{rpm}, 25^{\circ} \mathrm{C}\right)$. Obtained purified silk fibroin (SF) was subsequently lyophilized and kept in the freezer [58]. Finally, SF was dissolved in HFIP for electrospinning. The final concentration of the silk solution was $8 \% \mathrm{~m} / \mathrm{V}$.

The r-PET solution and silk solution were blended to obtain the solutions for electrospinning ratios, as summarized in Table 1.

Table 1. Content of solutions prepared for electrospinning.

\begin{tabular}{ccccc}
\hline Sample & $\begin{array}{c}\mathbf{1 0} \%(\mathbf{m} / \mathbf{V}) \text { of r-PET } \\
{[\mathbf{m L}]}\end{array}$ & $\begin{array}{c}\mathbf{8 \%}(\mathbf{m} / \mathbf{V}) \text { of SF } \\
{[\mathbf{m L}]}\end{array}$ & $\begin{array}{c}\text { SF Content in } \% \\
(V / V)\end{array}$ & $\begin{array}{c}\text { Total Concentration } \\
(\%)\end{array}$ \\
\hline r-PET & 4 & 0 & 0 & 10 \\
r-PSF1 & 4 & 0.2 & 4.7 & 9.9 \\
r-PSF2 & 4 & 0.4 & 9 & 9.8 \\
r-PSF3 & 4 & 0.8 & 16.6 & 9.6 \\
r-PSF4 & 4 & 1.6 & 28.5 & 9.4 \\
r-PSF5 & 4 & 2.4 & 37.5 & 9.2 \\
r-PSF6 & 4 & 4.8 & 54.5 & 8.9 \\
r-PSF7 & 4 & 9.6 & 70.5 & 8.5 \\
SF & 0 & 4 & 100 & 8 \\
\hline
\end{tabular}




\subsubsection{Electrospinning Process (ESP)}

The fibrous mats were prepared using an electrospinning device under ambient temperature $\left(23 \pm 1^{\circ} \mathrm{C}, \mathrm{H}=57 \pm 2 \%\right)$ in a horizontal spinning configuration with a flat-end needle with a $0.8 \mathrm{~mm}$ (21 gauge) inner diameter. The working distance was $12 \mathrm{~cm}$. The applied voltage was between $16-18 \mathrm{kV}$, with positive polarity, and voltage was driven by a high-voltage power supply (Spellman SL-150W, Bochum, Germany). The solutions were fed by a single syringe pump model NE-1000 (New Era Pump Systems, Inc., Farmingdale, NY, USA). The feeding rate was $0.15 \mathrm{~mL} \cdot \mathrm{h}^{-1}$. The electrospun fibers were collected on aluminum foil.

\subsubsection{Morphology of Fibers and Pores Size}

The morphology of investigated electrospun fibrous mats was observed by scanning electron microscopy (SEM) and JSM Jeol 6610 microscope (Jeol Ltd., Tokyo, Japan) at accelerated voltage $15 \mathrm{kV}$. The samples were sputtered with a thin layer of gold. Software AzTec (Springfield, NJ, USA) was used to collect figures and process the results. The average diameter of the fibers in the mats was measured utilizing Image J software (LOCI, University of Wisconsin, Madison, WI, USA). At least 100 segments were measured on the 5 independently prepared samples to ensure the accuracy of the average diameters of the fibers and their distributions.

The procedure described by Bandeira et al. [59] was used to prepare samples for SEM analysis of biofilms on electrospun fibers after antibacterial testing. First, the samples were washed twice with phosphate buffer solution (PBS, pH 7.4). Next, electrospun fibers were fixed with $4 \%$ paraformaldehyde for $30 \mathrm{~min}$. Next, the samples were washed twice with PBS for $10 \mathrm{~min}$ and distilled water for $10 \mathrm{~min}$. Subsequently, the samples were dehydrated with the addition of $25 \%, 50 \%, 70 \%$, and $95 \%$ ethanol for $10 \mathrm{~min}$ and absolute ethanol twice for $15 \mathrm{~min}$ at room temperature.

The average pore size of membranes was determined from the SEM images with Adobe Creative Suite software (CS5, Adobe Systems Inc., San Jose, CA, USA) and calculated from more than 60 values on the 5 independently prepared samples.

\subsubsection{Attenuated Total Reflectance-Fourier Transform Infrared Spectrometry (ATR-FTIR)}

Spectrophotometer Nicolet 8700 (Thermo Fisher Scientific, Madison, WI, USA) for Fourier transform infrared spectra recording, with DTGS TEC detector in mid-infrared scan range $600-4000 \mathrm{~cm}^{-1}$ with resolution $4 \mathrm{~cm}^{-1}$, was used in the absorbance mode. In addition, the spectrophotometer was equipped with a thermoelectrically cooled (TEC) fast-recovery DTGS detector. The spectra were measured in reflectance mode using the ATR (Attenuated Total Reflectance) accessory (Ge crystal was used as an optical window).

\subsubsection{Water Contact Angle (WCA)}

Static water contact angle measurements of all investigated mats were performed at room temperature $\left(22 \pm 1^{\circ}\right)$. Water droplets were used with a drop volume of $20 \mu \mathrm{L}$. The camera Canon Power Shot SX130 (Tokyo, Japan) was used for taking images. The baseline was estimated at the surface of the investigated mats and droplet interaction. The tangential line from the point of contact and the droplet's outer surface was drawn using the ImageJ software (LOCI, University of Wisconsin, Madison, WI, USA). The angles between these two lines were recorded as the mean contact angle. The contact angle was assessed from at least 5 values on the 3 independently prepared samples.

\subsubsection{Mechanical Analysis}

The tensile test was performed at room temperature using a Dynamometer Instron 4301 (Instron Corporation, Norwood, MA, USA) following standard ASTM D638. Seven testing strips for each formulation were cut from the electrospun mats with the dimensions of the tested strip area of $15 \times 15 \mathrm{~mm}$ with a thickness of approximately $0.1 \mathrm{~mm}$. The initial length of the tested strips was $120 \mathrm{~mm}$ because of better handling, and the gripping 
distance was $50 \mathrm{~mm}$. A testing rate of $1 \mathrm{~mm} \cdot \mathrm{min}^{-1}$ was applied until $0.5 \%$ deformation was reached, and then the rates were increased to $20 \mathrm{~mm} \cdot \mathrm{min}^{-1}$. Average values of the tensile strength $\left(\sigma_{\mathrm{TS}}\right)$, elongation at break $\left(\varepsilon_{\mathrm{B}}\right)$, and Young's modulus $(E)$ was determined from the stress-strain curves. The mechanical analysis was assessed from at least 5 values on the 3 independently prepared samples.

\subsubsection{Dynamic Mechanical Thermal Analysis (DMTA)}

Dynamic mechanical thermal analysis was performed using the Dynamic Mechanical Analyser DMAQ800 (TA Instruments, New Castle, DE, USA) within the temperature range from $-20{ }^{\circ} \mathrm{C}$ to $160{ }^{\circ} \mathrm{C}$ with a heating rate of $3{ }^{\circ} \mathrm{C} \cdot \mathrm{min}^{-1}$. The measurements were carried out in tensile mode at $1 \mathrm{~Hz}$ frequency with deformation amplitude of $20 \mu \mathrm{m}$. The storage modulus ( $\left.E^{\prime}\right)$, loss modulus ( $\left.E^{\prime \prime}\right)$, and loss tan delta $\left(\tan \delta=E / E^{\prime \prime}\right)$ were determined for at least three specimens of each sample formulation. The mechanical analysis was assessed from at least 5 values on the 3 independently prepared samples.

\subsubsection{Thermogravimetric Analysis (TGA)}

Linseis Combined thermal analyzer L75/L81/2000 (Linseis Messgeraete GmbH, Selb, Germany) was used for thermogravimetric measurements. Approximately $20 \mathrm{mg}$ of the investigated samples were loosely filled into a smaller cylindrical crucible (height: $14.0 \mathrm{~mm}$, diameter: $6 \mathrm{~mm}$ ) of TG. The analyses were carried out in the nitrogen atmosphere with the flow $12 \mathrm{~L} \cdot \mathrm{h}^{-1}$. The temperature was increased from $30^{\circ} \mathrm{C}$ up to $500^{\circ} \mathrm{C}$ with the heating and cooling rate of $10^{\circ} \mathrm{C} \cdot \mathrm{min}^{-1}$.

\subsubsection{Filtration Efficiency $(\mathrm{FE})$ and Quality Factor $\left(\mathrm{Q}_{\mathrm{f}}\right)$}

The filtration efficiency of selected samples (r-PET, r-PSF3, r-PSF6, and SF) was determined precisely on instrument MFP 1000 HEPA (Palas GmbH, Karlsruhe, Germany) according to the requirements of the standard EN 1822 for high effective air filters (EPA, HEPA, and ULPA) and EN 149 for respiratory protective devices, filtering half masks to protect against particles. DEHS fluid suitable for producing steady aerosols was used as testing particles with the particles size $120-2460 \mathrm{~nm}$. Face velocity $5.3 \mathrm{~cm} \cdot \mathrm{s}^{-1}$ and total volume flow was $32 \mathrm{~L} \cdot \mathrm{min}^{-1}$.

The quality factor $\left(\mathrm{Q}_{\mathrm{f}}\right)$ judges the relative overall performance of different membranes is calculated from the measurement of filtration efficiency $(\mathrm{FE})$ and drop pressure $(\Delta \mathrm{P})$. It is defined as in Equation (1) [45].

$$
Q_{f}=\frac{-\ln (1-F E)}{\Delta P}
$$

$Q_{f}$ is fairly independent of basis weight [60].

The filtration efficiency was assessed from the 3 independently prepared samples.

\subsubsection{Air Permeability (B)}

FX3300 air permeability tester III (Artec Testnology, Hertogenbosch, Netherlands) was used to measure air permeability. The measurement pressure was set to $100 \mathrm{~Pa}$, and the test sample's dimension was $20 \times 20 \mathrm{~cm}$. The results were evaluated according to EN ISO 9237. The air permeability was assessed from the 3 independently prepared samples.

\subsubsection{Water Vapor Permeability (WVP)}

The vapor permeability was measured using the PERMETEST Sensora Skin Model (Sensora, Liberec, Czech Republic) [61,62]. The device provides measurements required in the ISO Standard 11092. The measurements were carried out at laboratory temperature $20-22{ }^{\circ} \mathrm{C}$, and the laboratory water vapor concentration (humidity) of the parallel airflow $45-60 \%$ was applied. The samples with dimensions $12 \times 12 \mathrm{~cm}$ were used. The water vapor permeability was assessed from the 3 independently prepared samples. 


\subsubsection{Antibacterial Activity (R)}

Antimicrobial activity of electrospun pure r-PET, r-PSF6, and SF pure fibrous mats was determined with adherence to the procedure following ISO 22196:2011 for S. aureus and E. coli [63]. Bacterial suspensions were prepared at concentration between $2.5 \times 10^{5}$ to $10 \times 10^{5}$ cells $\cdot \mathrm{mL}^{-1} .400 \mu \mathrm{L}$ of the suspension was put on the surface of specimen $40 \mathrm{~mm} \times 40 \mathrm{~mm}$ in each sample, covered with a square piece of polyethylene film. The samples and the polyethylene films were placed under UV light for $30 \mathrm{~min}$ to sterilize them just before the experiments. After the contact time of $24 \mathrm{~h}$, the specimens (samples) were rinsed with CPLP broth (10 mL; Casein-peptone lecithin polysorbate broth (base)) on a petri dish, and the value for CFU. $\mathrm{mL}^{-1}$ was determined. Log reduction in the number of living and viable cells of tested bacteria (R) was calculated according to Equation (2):

$$
R=\left(U_{t}-U_{0}\right)-\left(A_{t}-U_{0}\right)=U_{t}-A_{t}
$$

where $U_{0}$ is the average value for the common logarithm of the number of viable bacteria, in cells $\mathrm{cm}^{-2}$, recovered from the control samples (r-PET) immediately after inoculation, $U_{t}$ is the mean for the common logarithm of the number of viable bacteria, in cells $\cdot \mathrm{cm}^{-2}$, recovered from the control samples after $24 \mathrm{~h}, A_{t}$ mean for the common logarithm of the number of viable bacteria in cells $\cdot \mathrm{cm}^{-2}$ is retrieved from the test sample (r-PSF6) after $24 \mathrm{~h}$.

Antimicrobial test results are given as means of 3 experiments \pm SD. The differences between the given groups were tested for statistical significance using Student's $t$-test $\left({ }^{*} p<0.05 ;{ }^{* *} p<0.01 ;{ }^{* * *} p<0.001\right)$.

\subsubsection{Biocompatibility}

The cells (HaCaT) were cultivated in Dulbecco's Modified Eagle Medium (DMEM) supplemented with $10 \%$ fetal calf serum (FCS) and antibiotics (penicillin $100 \mathrm{U} \cdot \mathrm{mL}^{-1}$; streptomycin $100 \mu \mathrm{g} \cdot \mathrm{mL}^{-1}$ ). The cells were cultured in a humidified atmosphere of $5 \% \mathrm{CO}_{2}$ at $37^{\circ} \mathrm{C}$.

Cytotoxicity of selected samples r-PET, r-PSF6, and SF were determined using the MTT method. Briefly, $2 \times 10^{4}$ cells were seeded in 96-well plates and cultured in a complete DMEM medium. The studied r-PET, r-PSF6, and SF were then added, and the cells were incubated at $37^{\circ} \mathrm{C}$ in a $5 \% \mathrm{CO}_{2}$ atmosphere for 24 and $48 \mathrm{~h}$. Next, the samples were washed with phosphate-buffered saline (PBS) at the indicated time point, followed by incubation with $1 \mathrm{mg} \cdot \mathrm{mL}^{-1}$ of MTT for $4 \mathrm{~h}$. Then, the MTT was removed, and the formazan crystals were dissolved with dimethyl sulfoxide for $30 \mathrm{~min}$. Absorbance at a wavelength of $540 \mathrm{~nm}$ was measured using an xMark microplate Spectrophotometer (Bio-Rad Laboratories, Inc., Hercules, CA, USA), and background absorbance at $690 \mathrm{~nm}$ was subtracted. The results are presented as mean \pm SD in quadruplicates $(n=4)$ from three independent experiments.

\section{Results and Discussion}

In this study, post-consumer bottle PET and silk fibroin regenerated from the silkworm cocoons were selected as readily available and cheap (only a few cents per kilogram $[64,65]$ ) materials to prepare fibrous mat's potential for filtration application. Polyethylene terephthalate is insoluble in common organic or aqueous solvents. The solvents in this study had to be selected regarding electrospinnability. PET has been already electrospun from a trifluoroacetic acid (TFA), a mixture of TFA/DCM $[44,66,67]$ in various portions or from HFIP and HFIP/DCM $[33,68]$. In the case of silk fibroin, it has been proven many times that the SF could be electrospun from aqueous solutions only with the aid of an auxiliary polymer [69,70]; however, it was successfully electrospun from formic acid (FA), TFA, and HFIP [58,70,71].

Regarding the solubility of both parts of the composite in the HFIP and the previous good results of authors, it has been used in the mixture with DCM [33]. HFIP has been used as a solvent of low-soluble synthetic polymers as well as protein-based natural polymers [72,73]. Dichloromethane is widely used in the pharmaceutical industry as a 
process solvent for that the Food and Drug Administration (FAD) has established residue tolerances [74]. The solution mixtures prepared according to Table 1 were processed by electrospinning process according to the parameters mentioned in Section 2.2.2.

The quality of fibrous mats is affected by several parameters $[75,76]$. Therefore, the processing parameters such as applied voltage, flow rate, needle top to collector distance, and concentration of solutions were selected by gradually experimenting to get the beadsfree fibers with the average diameter to ensure high filtration efficiency. This effort was made because the morphology of the fibers was shown to be highly correlated to the membrane properties, particularly in terms of fiber diameter and porosity [60]. In addition, the suitable concentrations of individual PET and SF stock solutions and parameters, such as flow rate, working distance, and voltage, were adjusted in preliminary experiments.

\subsection{Morphology of Electrospun Mats and Average Diameter of the Fibers}

Free-standing fibrous mats were produced. The morphology was assessed by SEM, and the micrographs of all prepared membranes are displayed in Figure 1. The micrographs show that the membranes contain randomly oriented, continuous, smooth fibers and beads were rarely observed. Compared to the pure r-PET nanofiber, it was found that the addition of silk fibroin induced the formation of thinner nanofiber.
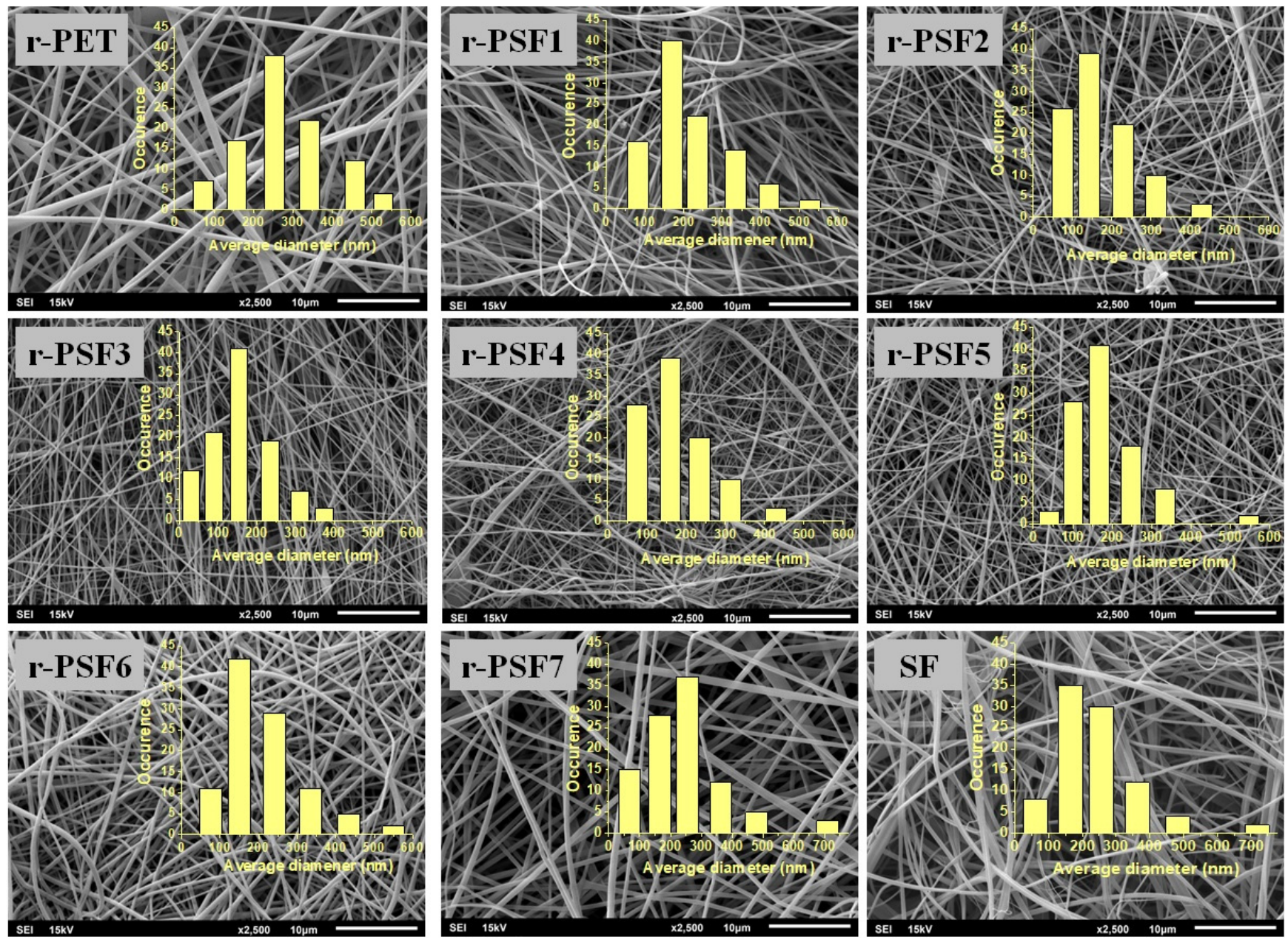

Figure 1. SEM micrographs of electrospun mats with varying amounts of silk.

Measuring the diameters of nanofibers is one of the important tools to assess the uniformity of mats [77]. Therefore, mean averages of fiber diameters were calculated from 100 individual fibers for each sample. Summarized average fiber diameters in investigated membranes are listed in Table 2 . The average diameter was changing with the increasing 
concentration of silk fibroin. As the content of SF increased, the total polymer solution concentration decreased, and the critical concentration was achieved for sample r-PSF3 with an average diameter of $127 \pm 50 \mathrm{~nm}$. This can be caused by the reduced viscosity of the blended solution because a lower viscosity of the solution leads to a thinner fiber diameter [78]. Then with the further increase of the SF concentration, the average diameter grew again, and fiber diameters distribution increased. Generally, with the further decreasing total concentration, the formation of the beads was expected. However, the results here show that the nanofiber characteristics cannot be attributed to a single composition parameter. Thus, the interaction effects of the formulation compositions must also be taken into account, as it has already been studied [79].

Table 2. List of average diameters (AD), the mean pore size of the fibers in the mats, and contact angles of all investigated electrospun membranes.

\begin{tabular}{cccc}
\hline Sample & AD \pm SD (nm) & $\begin{array}{c}\text { Mean Pore Size } \pm \text { SD } \\
(\mathbf{n m})\end{array}$ & Contact Angle $\left(^{\circ}\right)$ \\
\hline r-PET & $232 \pm 118$ & $850 \pm 331$ & $95 \pm 3$ \\
r-PSF1 & $168 \pm 83$ & $654 \pm 344$ & $94 \pm 2$ \\
r-PSF2 & $134 \pm 63$ & $352 \pm 124$ & $92 \pm 3$ \\
r-PSF3 & $127 \pm 50$ & $348 \pm 121$ & $86 \pm 1$ \\
r-PSF4 & $139 \pm 76$ & $398 \pm 104$ & $61 \pm 4$ \\
r-PSF5 & $146 \pm 103$ & $427 \pm 140$ & $51 \pm 9$ \\
r-PSF6 & $149 \pm 89$ & $480 \pm 188$ & $43 \pm 4$ \\
r-PSF7 & $253 \pm 125$ & $975 \pm 345$ & $31 \pm 5$ \\
SF & $202 \pm 128$ & $828 \pm 380$ & $10 \pm 1$ \\
\hline
\end{tabular}

As can be seen from Table 2, the estimated pore size of r-PET and SF mats was larger than that of fibrous composites (except r-PSF7) and showed a decreasing trend with the decrease of fiber diameter. This trend is consistent with other electrospun nanofiber membrane investigations, where the larger pore size is obtained when fiber diameter increased [43].

\subsection{Water Contact Angle (WCA)}

The WCA of pure r-PET, SF, and composite r-PSFs membranes were investigated. The values of contact angles are given in Table 2 . The r-PET fibrous membrane was more hydrophobic, with a mean water contact angle of $95 \pm 3^{\circ}$. However, the water droplet spread out almost immediately in pure SF case and penetrated the fibrous membrane. The contact angle of SF was $10 \pm 1{ }^{\circ} \mathrm{C}$ at the moment of drop impact. Next, in fibrous composites r-PSF3, r-PSF4, r-PSF5, and r-PSF6, the hydrophobicity decreased with the increased proportion of $\mathrm{SF}$, indicating that $\mathrm{SF}$ improved the hydrophilicity in comparison to r-PET. These results demonstrate that the SF considerably affects the surface wettability of the fibrous membranes, making the structure more hydrophilic, which is in good agreement with available literature [80]. Silk fibroin fibers can be hydrophilic due to the high number of the amino group and carboxylic acid domains they contain [81]. In liquid/aerosol filtration applications, the filtration performance is closely related to the wettability of the filtration media due to different shapes of droplets, barrel, or clamshell, on the fiber surface and various positions of liquid films present on the filter surface during filtration processes [82]. Furthermore, wettability is an advantageous property that can save operating costs in filtration due to the need for lower energy to push the liquid during filtration through the hydrophilic filtration medium [83].

\subsection{ATR-FTIR Analysis of Investigated Fibrous Mats}

ATR-FTIR is a common tool for investigating the chemical compositions and molecular conformations of polymers and composite materials [84]. The ATR-FTIR spectra of the electrospun r-PET, SF, and r-PSF4-r-PSF7 with SF concentration from $28.5-70.5 \%(V / V)$ are shown in Figure 2. 


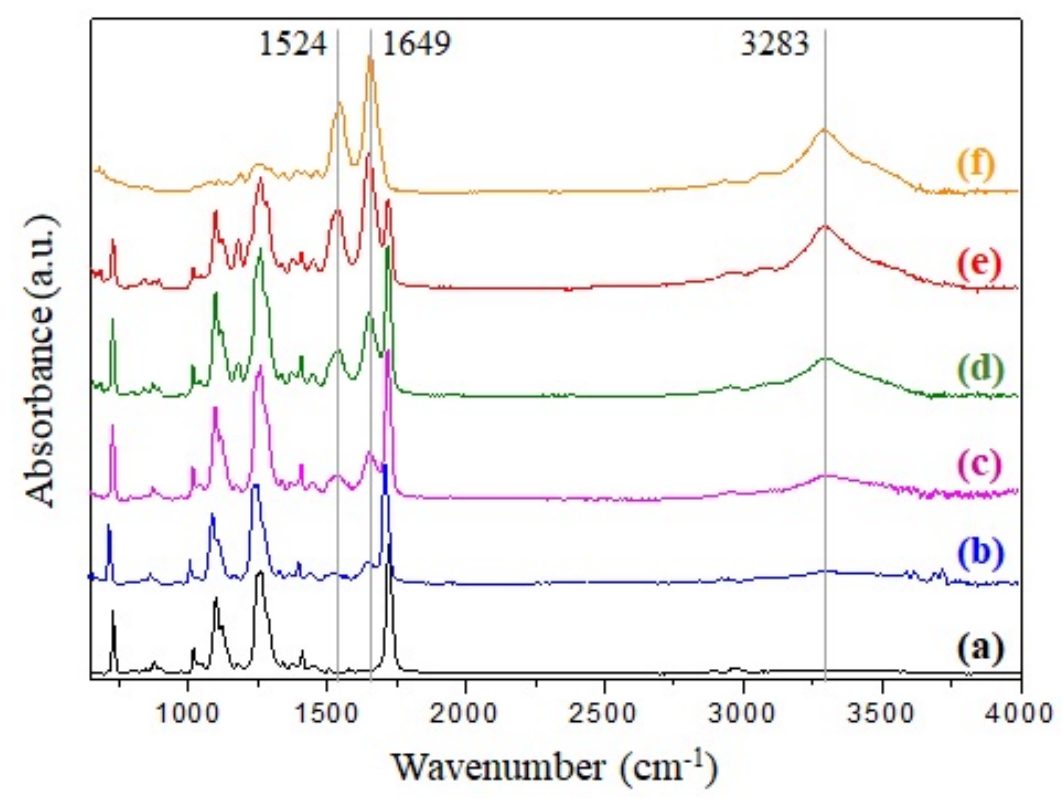

Figure 2. FTIR spectra of (a) r-PET, (b) r-PSF4, (c) r-PSF5, (d) r-PSF6, (e) r-PSF7, (f) SF.

The common characteristics bands of poly(ethylene terephthalate) are observed in Figure 2a. The band at $724 \mathrm{~cm}^{-1}$ is attributed to the interaction of polar ester groups and benzene rings, at $1265 \mathrm{~cm}^{-1}$ to the terephthalate group $\left(\mathrm{OOCC}_{6} \mathrm{H}_{4}-\mathrm{COO}\right)$, at $1050 \mathrm{~cm}^{-1}$ to ester $\mathrm{C}-\mathrm{O}$ bond, and band at $1714 \mathrm{~cm}^{-1}$ is corresponding to $\mathrm{C}=\mathrm{O}$ stretching $[85,86]$.

Enhancing of the bands in the case of r-PSF4, r-PSF5, r-PSF6, r-PSF7 (Figure 2b-e) belonging for the amide groups of silk at $1240 \mathrm{~cm}^{-1}$ (amide III, C-N stretching), $1649 \mathrm{~cm}^{-1}$ (amide I, C=O stretching), $1524 \mathrm{~cm}^{-1}$, and $3283 \mathrm{~cm}^{-1}$ (amide II, N-H bending) correspond to the increasing of SF concentration, which was attributed to the random coil, $\alpha$-helix, and $\beta$-sheet structure of silk fibroin $[58,87,88]$. These bands are compared to the bands of pure silk fibroin located in the spectrum depicted in Figure 2f. Electrospun mats with a lower concentration of SF than $28.5 \%(V / V)$ were investigated by ATR-FTIR as well; however, the typical bands at $1524 \mathrm{~cm}^{-1}$ and $1649 \mathrm{~cm}^{-1}$ have not been observed yet, and therefore the spectra are not shown here. The ATR-FTIR measurements of prepared membranes were carried out from both sides of the membranes; however, the results are compared and therefore are not presented.

\subsection{Mechanical Properties}

The mechanical properties of the electrospun membranes intended to serve as filtration media in personal protection are important parameters because such membranes are stretched in all directions during the application. To investigate the characteristics of electrospun r-PSFs mats, tensile tests for samples with a basic weight $10-12 \mathrm{~g} \cdot \mathrm{m}^{-2}$ were performed to understand how the different compositions affected mechanical properties. The stress-strain curves for pure r-PET and all r-PSFs membranes differ in SF concentration for direct comparison are shown in Figure 3. There are significant differences in terms of their mechanical behavior. As can be seen from the inset of Figure 3, the pure SF shows brittle behavior, reflecting weak mechanical resistance. The determination of the mechanical properties of the fibrous mats revealed that the increasing SF loading was leading to $\sigma_{\mathrm{TS}}$ increases due to SF fibrous structure, reflected in high tensile strength and flexibility. 


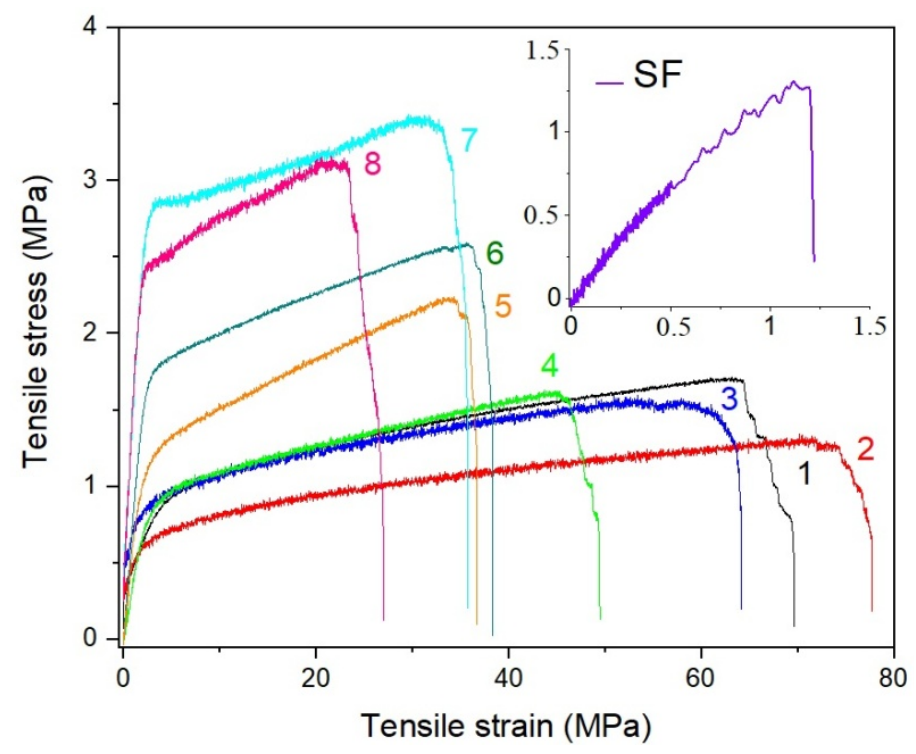

Figure 3. Stress-strain curves for r-PET electrospun mats contained (1) r-PET pure, (2) r-PSF1, (3) r-PSF2, (4) r-PSF3, (5) r-PSF4, (6) r-PSF5, (7) r-PSF6, (8) r-PSF7. The inset shows the stress-strain curve of crude electrospun SF.

On the contrary, the elongation at the break slightly increased with a small drop in tensile strength typically observed after the addition of plasticizer due to higher free volume. Increasing the SF volume, the r-PSF mats became more brittle with a continuous decline in elongation at break $\left(\varepsilon_{\mathrm{B}} / \sigma_{\mathrm{TS}}\right)$ as a function of $\mathrm{SF}$ content. Addition of the highest $\mathrm{SF}$ volume (r-PSF7) lead to extensive deterioration of mechanical properties, resulting in twice lower elongation at break than the pure r-PET mat $\left(\varepsilon_{\mathrm{B}} / \sigma_{\mathrm{TS}}\right.$ values are summarized in Table 3).

Table 3. Summarized results of mechanical testing.

\begin{tabular}{ccc}
\hline \multirow{2}{*}{ Sample } & \multicolumn{2}{c}{ Mechanical Analysis } \\
\cline { 2 - 3 } & $\boldsymbol{\sigma}_{\mathrm{TS}} \pm \mathbf{S}_{\boldsymbol{\sigma}}[\mathbf{M P a}]$ & $\boldsymbol{\varepsilon}_{\mathbf{B}} \pm \mathbf{S}_{\boldsymbol{\varepsilon}}[\%]$ \\
\hline r-PET & $1.62 \pm 0.11$ & $64.90 \pm 14.8$ \\
r-PSF1 & $1.28 \pm 0.19$ & $67.30 \pm 16.2$ \\
r-PSF2 & $1.32 \pm 0.21$ & $59.50 \pm 6.82$ \\
r-PSF3 & $1.49 \pm 0.13$ & $40.50 \pm 8.10$ \\
r-PSF4 & $1.85 \pm 0.26$ & $31.00 \pm 6.68$ \\
r-PSF5 & $2.75 \pm 0.29$ & $36.80 \pm 8.10$ \\
r-PSF6 & $3.45 \pm 0.50$ & $33.50 \pm 4.30$ \\
r-PSF7 & $3.10 \pm 0.37$ & $25.80 \pm 4.60$ \\
SF & $1.35 \pm 0.34$ & $1.89 \pm 0.60$ \\
\hline
\end{tabular}

Young's modulus (E) of the electrospun pure r-PET, r-PSF mats, containing different $\mathrm{SF}$ amounts is shown in Figure 4. Young's modulus is attributed to the strength of the interaction between fibers within the material that does not significantly depend on its thickness [89]. It was observed that increasing SF content in r-PSF samples increases the E. Similar behavior was reported by Gobin et al. [90], which attributed these changes to more numerous interactions of SF, with presented chitosan in the form of strong molecular hydrogen bonding. Hydrogen interactions can occur not only at the polymer filler interfacial, but also in the form of mutual particle interactions, especially at higher fibroin concentrations resulting in significant increase in stiffness. 


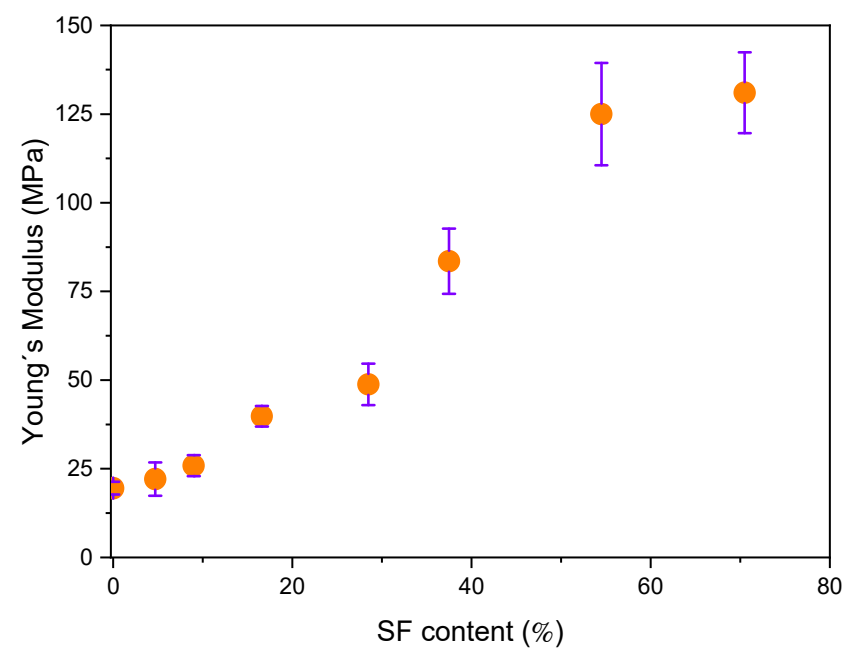

Figure 4. Changes of Young's modulus for r-PET electrospun mats as a function of content SF was varying from 0 to $70.5 \mathrm{~V} / \mathrm{V} \%$ (from r-PET to r-PSF7).

\subsection{Dynamic Mechanical Thermal Analysis}

The DMTA is a sensitive characterization method giving additional information at the level of phase or molecular structure within the polymer, such as crosslinking, branching, and crystallinity. The behavior of loss factor $(\tan \delta)$ and storage modulus ( $\left.E^{\prime}\right)$ for the electrospun r-PET mats contained varying SF concentrations and are compared in Figure 5. The pure r-PET exhibits one peak assigned to glass transition temperature $\left(\mathrm{T}_{\mathrm{g}}\right)$ at approximately $83^{\circ} \mathrm{C}$. Silk fibroin affected $\mathrm{T}_{\mathrm{g}}$ slightly shifted to the lower temperatures and reduced the maximum loss factor peak with increasing the SF content. Apparently, the presence of fibrous structure can significantly affect the mobility of the polymer chains due to acting as a heavy barrier for relaxation processes required for followed arrangement of the polymer chains. Figure $5 b$ shows the dependence of $E^{\prime}$ as a function of temperature for all the investigated electrospun mats. Generally, the observed changes in $E^{\prime}$ are associated with interface adhesion between polymer and fillers which can be related to changes within a material structure such as crosslinking, aging, or degradation [91]. As is clearly shown in Figure $5 \mathrm{~b}$ (black line), the $\mathrm{E}^{\prime}$ of neat r-PET mat shows a progressive decrease at around $80^{\circ} \mathrm{C}$ due to the glass transition from the glassy to rubbery state. The addition of SF (from 4.7 to $70.5 \%$ ) results in a gradual increase in $\mathrm{E}^{\prime}$ at $25^{\circ} \mathrm{C}$ as a consequence of limited chain mobility, reflecting in pronounced stiffness of the material. For the low SF concentrations, there is negligible increase in $\mathrm{E}^{\prime}$ of r-PET/SF electrospun mats compared to neat r-PET while at higher SF concentration (over $28.5 \%$ ), and the $\mathrm{E}^{\prime}$ increases dramatically due to effective reinforcing of presented SF and reaching approximately 15 times higher value compared to neat r-PET.

\subsection{Thermogravimetric Analysis (TGA)}

The TGA was used to estimate the thermal stability of the investigated samples. The results are shown in Figure 6. The first weight loss is observed close to $100{ }^{\circ} \mathrm{C}$ due to moisture loss and residual solvents. This first weight loss is around $5 \%$ and agrees in all samples.

The TGA curve of the electrospun r-PET shows stability up to the decomposition temperature at around $400{ }^{\circ} \mathrm{C}$. After that, the degradation reaction ceased at a residue accumulation of $20 \%$. It is in good agreement with published results when thermal degradation occurs under an inert environment [92]. Subsequently, the decomposition temperature decreases with the increasing concentration of SF in the investigated sample; however, the accumulation of residue is increasing. In r-PSF6, the decomposition temperature is around $250{ }^{\circ} \mathrm{C}$, and the accumulation of residue at $500{ }^{\circ} \mathrm{C}$ is $30 \%$. Unlike the r-PET, the sample r-PSF7 exhibits two steps of weight loss. First is at $100{ }^{\circ} \mathrm{C}$, and this decreasing passes into 
the plane between $180-250{ }^{\circ} \mathrm{C}$. The weight loss is $15 \%$. Then, the second and most significant weight loss starts at $250{ }^{\circ} \mathrm{C}$, corresponds to the degradation of silk. The accumulation weight loss at $500{ }^{\circ} \mathrm{C}$ is $35 \%$. The TGA curve of r-PSF7 exhibits the similarities of both types of polymers, r-PET, and SF as well. In the TGA curve of SF, the decomposition is also in the two steps; however, the plane after the first weight loss is shorter, between $180-230{ }^{\circ} \mathrm{C}$, as it was published by $[93,94]$.

a)

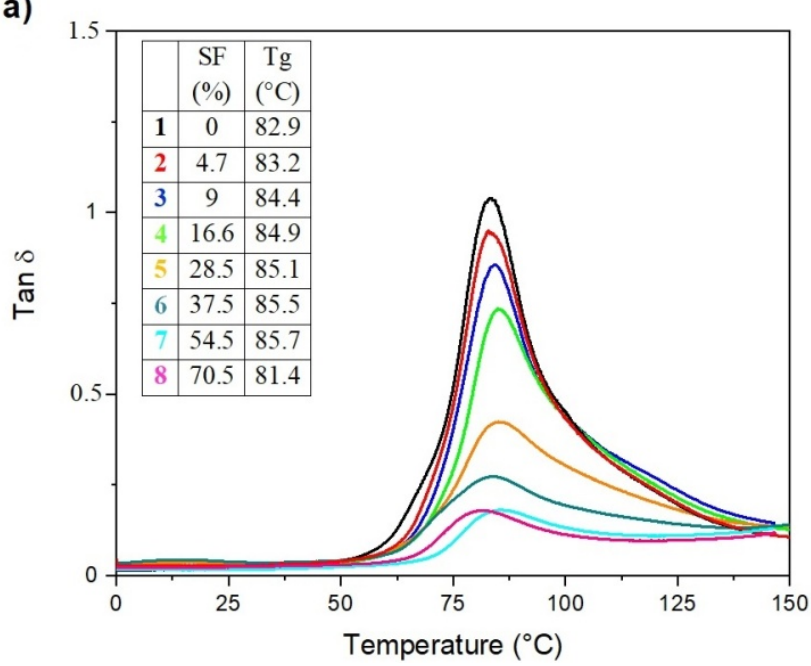

b)

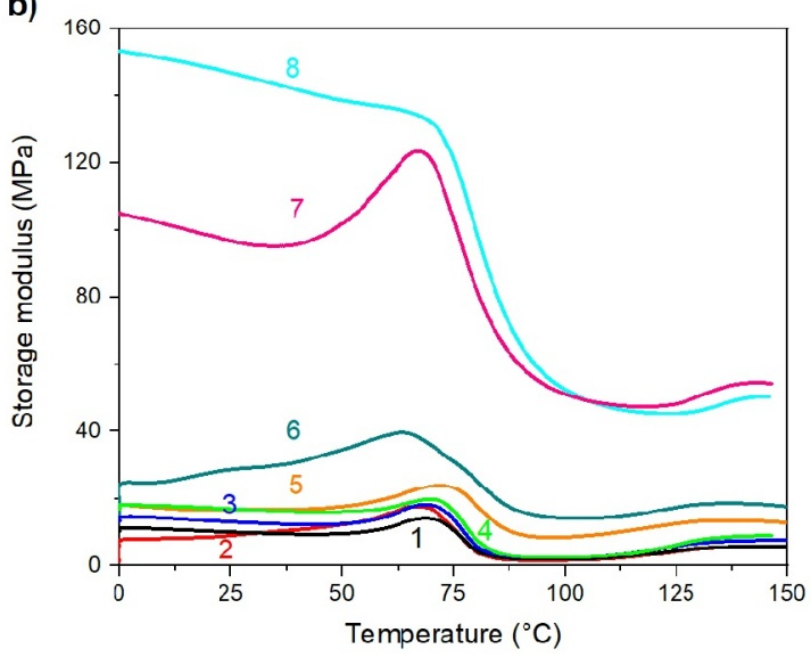

Figure 5. Evolution of loss factor $(\tan \delta)(\mathbf{a})$ and storage modulus $(\mathbf{b})$ with temperature of electrospun membranes containing (1) r-PET, (2) r-PSF1, (3) r-PSF2, (4) r-PSF3, (5) r-PSF4, (6) r-PSF5, (7) r-PSF6, (8) r-PSF7.

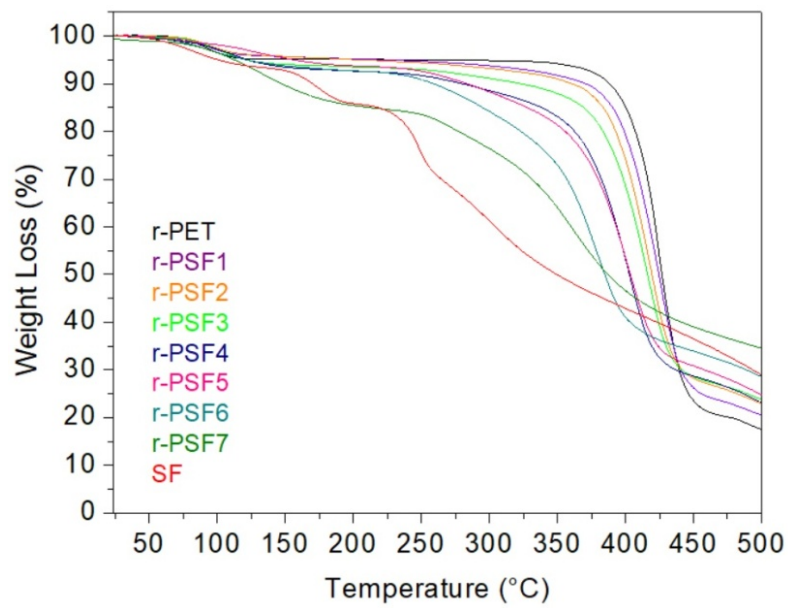

Figure 6. Thermogravimetric analysis of investigated membranes at temperatures between 30 and $500{ }^{\circ} \mathrm{C}$.

\subsection{Filtration Efficiency and Comfort Properties}

Advanced filtration technologies need to be designed to provide effective and reliable capture of particles under $300 \mathrm{~nm}$ sizes. Electrospun fibers have been widely used in many applications, especially in air filtration, due to the significantly large specific area, small fiber diameter, and porosity.

Herein, the filtration efficiency was established for the selected electrospun samples r-PET, r-PSF3, r-PSF6, and SF. The r-PSF3 was selected due to the smallest fiber diameter (Table 2) that indicates the high filtration efficiency and r-PSF6 for the equal amount of $\mathrm{r}$-PET and SF in the mixture. The membranes were electrospun in two different basis weight ranges: $10-12 \mathrm{~g} \cdot \mathrm{m}^{-2}$ (Table 4, Figure 7) and 1.75-3.23 $\mathrm{g} \cdot \mathrm{m}^{-2}$ (Table 6, Figure 8). 
Table 4. List of results from the filtration activity of investigated fibrous mats: SF pure, r-PSF3, r-PSF6, and r-PET pure. The basis weights of the investigated mats were between $10-12 \mathrm{~g} \cdot \mathrm{m}^{-2}$. The membranes were classified according to Standard EN149 and EN1822. The values are listed in the form mean \pm SD (standard deviation).

\begin{tabular}{|c|c|c|c|c|c|c|c|}
\hline Sample & $\begin{array}{l}\text { Basis Weight } \\
\quad\left(\mathrm{g} \cdot \mathrm{m}^{-2}\right)\end{array}$ & $\begin{array}{l}\text { Thickness } \\
\text { (mm) }\end{array}$ & $\begin{array}{c}{ }^{*} \mathrm{E}_{\text {MPPS }} \\
(\%)\end{array}$ & $\begin{array}{c}\Delta \mathbf{P} \\
(\mathbf{P a})\end{array}$ & $\underset{\left(\mathrm{Pa}^{-1}\right)}{\mathrm{Q}_{\mathrm{f}}}$ & $\begin{array}{l}\text { Filter Class } \\
\text { According to } \\
\text { EN149 }\end{array}$ & $\begin{array}{l}\text { Filter Class } \\
\text { According to } \\
\text { EN1822 }\end{array}$ \\
\hline r-PET & $12.01 \pm 0.01$ & $0.11 \pm 0.002$ & $99.97 \pm 0.2$ & $414 \pm 21$ & $0.019 \pm 0.001$ & High $\Delta \mathrm{P}$ & $\mathrm{H} 13$ \\
\hline r-PSF3 & $11.15 \pm 0.01$ & $0.11 \pm 0.002$ & $99.85 \pm 0.4$ & $272 \pm 14$ & $0.024 \pm 0.001$ & High $\Delta \mathrm{P}$ & E12 \\
\hline r-PSF6 & $10.25 \pm 0.01$ & $0.10 \pm 0.001$ & $98.99 \pm 1.9$ & $315 \pm 15$ & $0.015 \pm 0.001$ & $\operatorname{High} \Delta \mathrm{P}$ & E11 \\
\hline SF & $11.00 \pm 0.02$ & $0.11 \pm 0.002$ & $43.34 \pm 6.4$ & $47 \pm 8$ & $0.012 \pm 0.002$ & No classification & No classification \\
\hline
\end{tabular}

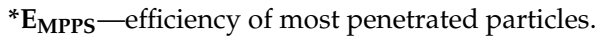

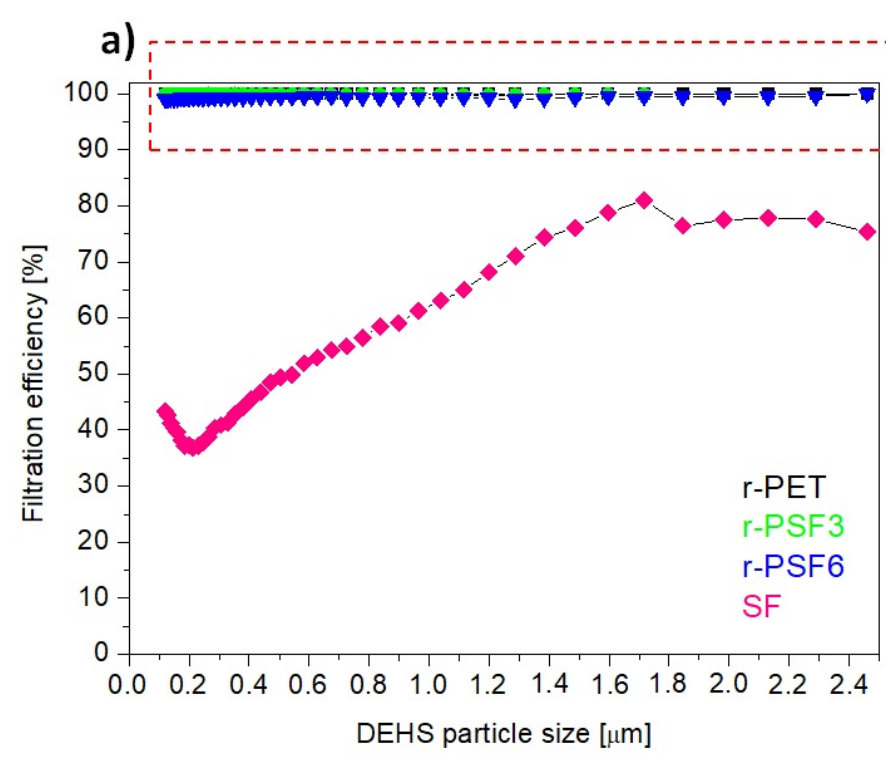

b)

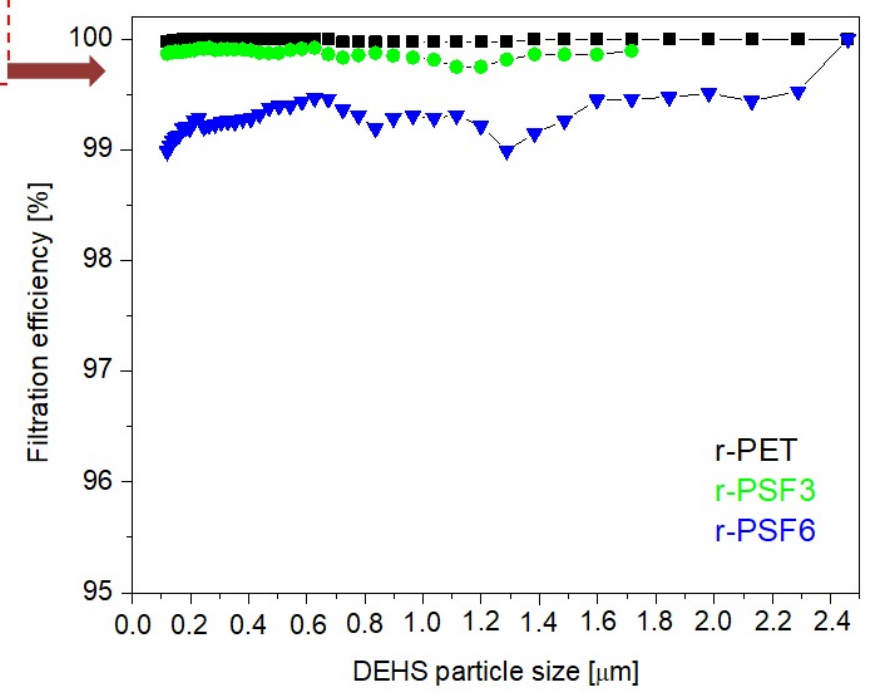

Figure 7. Filtration efficiency of investigated samples with basis weights between $10-12 \mathrm{~g} \cdot \mathrm{m}^{-2}$; (a) r-PET (black sign), r-PSF3 (green sign), r-PSF6 (blue sign), SF (magenta sign); (b) detail of the curves at high efficiency.

a)

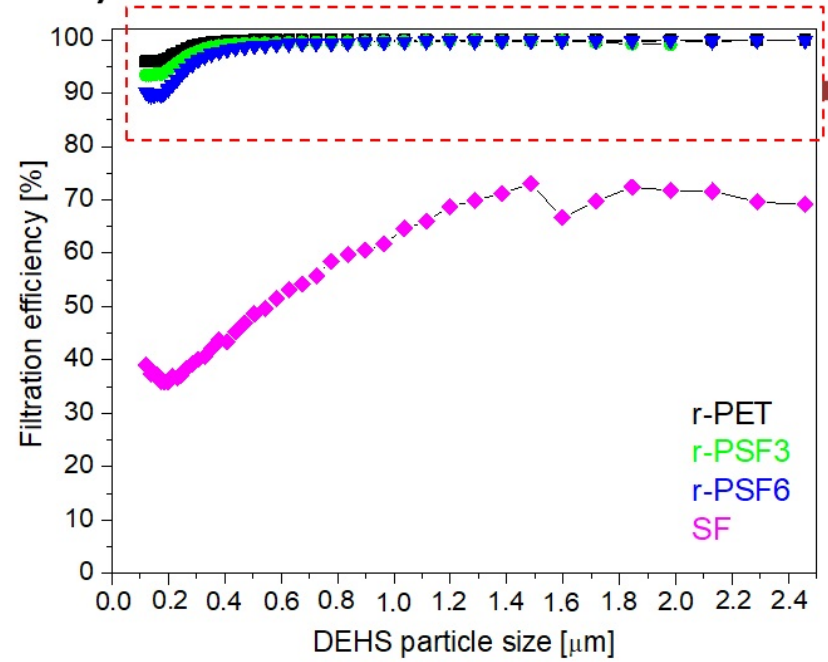

b)

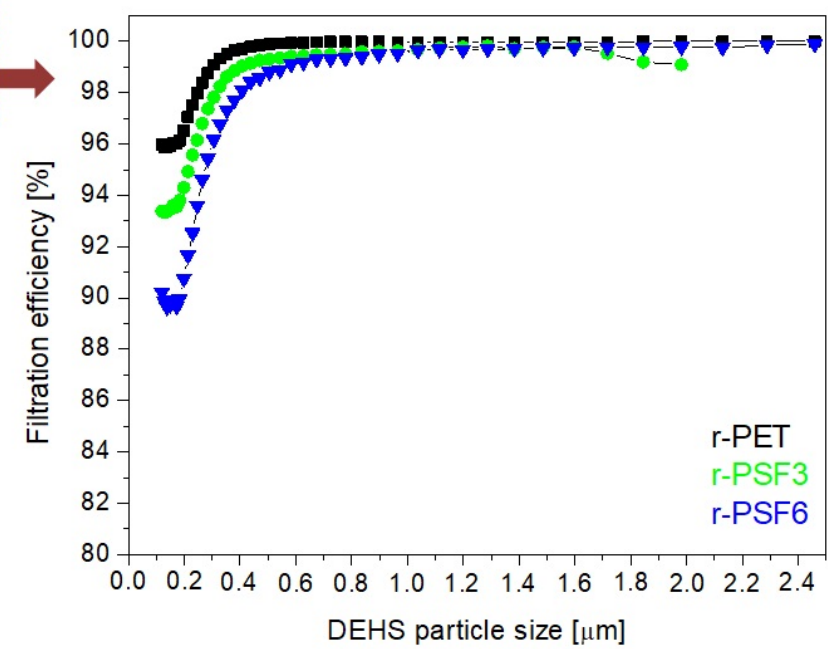

Figure 8. Filtration efficiency of investigated samples with basis weights between $1.75-3.23 \mathrm{~g} \cdot \mathrm{m}^{-2}$; (a) r-PET (black sign), r-PSF3 (green sign), r-PSF6 (blue sign), SF (magenta sign); (b) detail of the curves at high efficiency. 
Figure 7a shows the most representative curves of filtration efficiency of each type of the investigated membranes. Figure $7 \mathrm{~b}$ shows the detail of the curves representing the higher FE of the three discussed membranes. Figures show the trend of filtration efficiency in dependence on the DEHS particle size. The trend is not linear, and this nonlinear behavior could be explained by the filtration performance governed by filtration mechanisms, including inertial impaction, interception, electrostatic attraction, diffusion, and gravity sedimentation $[45,95,96]$. The mechanisms can also participate in the filtration simultaneously.

It is shown that at basis weight in the range $10-12 \mathrm{~g} \cdot \mathrm{m}^{-2}$, the r-PET, r-PSF3 exhibited filtration efficiency of more than $99 \%$ and r-PSF6 of $98.99 \%$ filtration efficiency as listed in Table 4.

However, the pressure drop measured in all three samples was too high to classify the membranes according to EN149 (Table 5) and to apply these membranes for personal protection. The higher pressures drop the worse breathability. It is always challenging to increase efficiency while maintaining low pressure drops [45].

Table 5. Division of respiratory protection into classification according to standard EN149 and EN1822, minimum efficiency of safety, maximal acceptable pressure drop at the total volume flow $30 \mathrm{~L} \cdot \mathrm{min}^{-1}$, and examples of protection [96,97].

\begin{tabular}{|c|c|c|c|}
\hline $\begin{array}{c}\text { Filtration Class } \\
\text { According to the EN149 }\end{array}$ & $\begin{array}{c}\text { Minimal Efficiency of } \\
\text { MPPA (\%) }\end{array}$ & $\begin{array}{l}\text { Recommended } \\
\text { Pressure Drop (Pa) } \\
\left(\text { at } 30 \mathrm{~L} \cdot \mathrm{min}^{-1}\right)\end{array}$ & Protection \\
\hline FFP1 & $\geq 80$ & 60 & $\begin{array}{l}\text { Solid inert particles, aerosols without } \\
\text { particular toxicity, e.g., calcium } \\
\text { carbonate, plaster, brick dust, } \\
\text { pollen, and fur. }\end{array}$ \\
\hline FFP 2 & $\geq 94$ & 100 & $\begin{array}{l}\text { Biological and carcinogenic } \\
\text { compounds, harmful solid particles, } \\
\text { toxic or irritating aqueous aerosols, e.g., } \\
\text { silica, sodium carbonate, iron, wood } \\
\text { and glass dust, water-soluble pesticides, } \\
\text { grain, mold, fungi, exhaust gasses. } \\
\text { Biological compounds, toxic solids, } \\
\text { aqueous aerosols, e.g., TBC bacteria, } \\
\text { asbestos, radioactive } \\
\text { beryllium particles. }\end{array}$ \\
\hline $\begin{array}{c}\text { Filtration Class } \\
\text { According to the EN1822 }\end{array}$ & $\begin{array}{c}\text { Minimal Efficiency of } \\
\text { MPPA (\%) }\end{array}$ & $\begin{array}{c}\text { Recommended } \\
\text { Final Pressure Drop (Pa) }\end{array}$ & Protection \\
\hline $\begin{array}{l}\text { E10 } \\
\text { E11 }\end{array}$ & $\begin{array}{l}\geq 85 \\
>95\end{array}$ & \multirow{4}{*}{$250-1000$ * } & \multirow{4}{*}{$\begin{array}{c}\text { germs, bacteria, metallic-oxide smoke } \\
\text { viruses, tobacco smoke, soot } \\
\text { oil fumes, radioactive } \\
\text { suspended particulates } \\
\text { aerosols }\end{array}$} \\
\hline E12 & $\geq 99.5$ & & \\
\hline H13 & $\geq 99.95$ & & \\
\hline H14 & $\geq 99.995$ & & \\
\hline
\end{tabular}

* Commercially available filters in classified into the class according to the EN1822.

Nevertheless, the pressure drop of r-PET, r-PSF3, and r-PSF6 is adequate for applying to EPA (Efficient Particulate Air filter) and HEPA (High Efficiency Particulate Air filter) filters in air ventilation and air conditioning, and these membranes could be classified according to standard EN1822 (Table 5) [96]. In general, the lower the pressure drop, the lower the operating costs. The SF membranes exhibited just $43 \%$, which is too low to be classified according to the mentioned standards. It follows that the FE depends not only on basis weight but also on the type of polymer and its properties [37]. The measured (exact basis weight, FE, and pressure drop) and calculated data of quality factor $\left(Q_{f}\right)$ are listed in Table 4 . The trade-off parameter $Q_{f}$ evaluates the filtration performance of a given filtration medium. From Table 4 it can be observed that the highest value of $Q_{f}$ obtains sample r-PSF3 with the thinnest fiber diameter. 
Figure 8a presents the most representative curves of filtration efficiency of each type of investigated membrane r-PET, r-PSF3, r-PSF6, and SF in the range of basis weight $1.75-3.23 \mathrm{~g} \cdot \mathrm{m}^{-2}$. Figure $8 \mathrm{~b}$ shows the detail of the curves representing the higher FE of the discussed three membranes with higher filtration effectivity. The r-PET, r-PSF3, and r-PSF6 exhibited filtration efficiency of more than $90 \%$. On the other hand, the SF membranes showed just $39 \%$ of FE. The measured (exact basis weight, FE, and pressure drop) and calculated data $\left(Q_{f}\right)$ are listed in Table 6.

Table 6. Summarized results from measurement of the filtration activity of investigated fibrous mats: SF, r-PSF3, r-PSF6, and $\mathrm{r}$-PET. The basis weights of the investigated mats were between $1.75-3.23 \mathrm{~g} \cdot \mathrm{m}^{-2}$. The membranes were classified according to Standard EN 149. The values are listed in the form mean \pm SD (standard deviation).

\begin{tabular}{|c|c|c|c|c|c|c|c|}
\hline Sample & $\begin{array}{l}\text { Basis Weight } \\
\quad\left(\mathrm{g} \cdot \mathrm{m}^{-2}\right)\end{array}$ & $\begin{array}{l}\text { Thickness } \\
(\mathrm{mm})(\mu \mathrm{m})\end{array}$ & $\begin{array}{c}{ }^{*} \mathrm{E}_{\mathrm{MPPS}} \\
(\%)\end{array}$ & $\begin{array}{c}\Delta \mathbf{P} \\
(\mathrm{Pa})\end{array}$ & $\underset{\left(\mathrm{Pa}^{-1}\right)}{\mathrm{Q}_{\mathrm{f}}}$ & $\begin{array}{l}\text { Filter Class } \\
\text { According to } \\
\text { EN149 }\end{array}$ & $\begin{array}{l}\text { Filter Class } \\
\text { According to } \\
\text { EN1822 }\end{array}$ \\
\hline r-PET & $3.23 \pm 0.02$ & $0.08 \pm 0.003$ & 95.98 & $123 \pm 4.4$ & 0.026 & High $\Delta \mathrm{P}$ & E11 \\
\hline r-PSF3 & $2.08 \pm 0.02$ & $0.07 \pm 0.001$ & $93.38 \pm 0.9$ & $92 \pm 2.6$ & $0.030 \pm 0.001$ & High $\Delta \mathrm{P}$ & E10 \\
\hline r-PSF6 & $2.65 \pm 0.01$ & $0.08 \pm 0.001$ & $90.23 \pm 2.7$ & $59 \pm 2.2$ & $0.039 \pm 0.001$ & FFP1 & E10 \\
\hline SF & $1.75 \pm 0.03$ & $0.07 \pm 0.001$ & $39.01 \pm 6.4$ & $27 \pm 9.6$ & $0.018 \pm 0.002$ & No classification & No classification \\
\hline
\end{tabular}

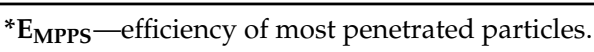

The filtration effectivity, as well as the pressure drop, depends on the basis weight. On the other hand, the quality factor does not depend on the basis weight, and it is the biggest for the r-PSF6. The larger $Q_{\mathrm{f}}$ indicates a more excellent filtration performance, but not for very efficient filters because the efficiency growth over $90 \%$ is usually lower than the pressure drop growth. Therefore, the higher effectivity in r-PSF3 is more important; this can prove that the fiber diameter plays a role in the FE.

The range of application is determined by the type of filter FFP1, FFP2, and FFP3, which determines the amount and kind of trapped particles (Table 5). According to the FE in this series of the samples (Table 6), the r-PSF6 could be classified as FFP1, which corresponds to the standard face masks most commonly used by residents during the pandemic. The membranes r-PET, r-PSF3, and r-PSF6 could be classified again according to EN1822 to the class E10 and E11, as is listed in Table 6.

\subsection{Air and Water Vapor Permeability}

For the applications for which the membranes under investigation are intended, the air permeability (B) is a key indicator, because good air permeability provides good microenvironment. Moreover, better air permeability means better flux [98]. Therefore, there is a growing urge to investigate membrane air permeability. Herein, air permeability of the selected membranes r-PET, r-PSF3, r-PSF6, and SF was measured, and the results are listed in Table 7.

Table 7. Results of air permeability (B) and water vapor permeability (WVP). The values are listed in the form mean $\pm \mathrm{SD}$ (standard deviation).

\begin{tabular}{cccccc}
\hline \multirow{2}{*}{ Sample } & Basis Weight & \multicolumn{2}{c}{$\mathbf{1 . 7 5 - 3 . 2 3} \mathbf{( g \cdot \mathbf { m } ^ { - \mathbf { 2 } } )}$} & \multicolumn{2}{c}{$\mathbf{1 0 - 1 2} \mathbf{( g \cdot \mathbf { m } ^ { - \mathbf { 2 } } )}$} \\
\cline { 3 - 6 } & & $\begin{array}{c}\mathbf{B} \\
\left(\mathbf{L} \cdot \mathbf{m m} \cdot \mathbf{s}^{-\mathbf{1}}\right)\end{array}$ & $\begin{array}{c}\text { WVP } \\
\mathbf{( \% )}\end{array}$ & $\begin{array}{c}\text { B } \\
\left(\mathbf{L} \cdot \mathbf{m m} \cdot \mathbf{s}^{-\mathbf{1}}\right)\end{array}$ & $\begin{array}{c}\text { WVP } \\
\mathbf{( \% )}\end{array}$ \\
\hline r-PET & $53.4 \pm 2.7$ & $89.2 \pm 1.5$ & $39.8 \pm 2.4$ & $94.7 \pm 1.0$ \\
r-PSF3 & $117.0 \pm 4.2$ & $86.5 \pm 1.7$ & $54.6 \pm 3.9$ & $89.2 \pm 1.4$ \\
r-PSF6 & $149.9 \pm 5.7$ & $88.9 \pm 1.7$ & $85.0 \pm 7.0$ & $89.9 \pm 1.3$ \\
SF & $201.3 \pm 8.3$ & $89.3 \pm 2.0$ & $150.0 \pm 9.1$ & $89.5 \pm 1.9$ \\
\hline
\end{tabular}

Many parameters, such as fiber diameter, pores size, basis weight, and the surface wettability of the membrane, can affect the air and water vapor permeability of nanofibers membrane. In this study, air permeability was measured for the selected samples with a 
higher basis weight $\left(10-12 \mathrm{~g} \cdot \mathrm{m}^{-2}\right)$ and the smaller basis weight $\left(1.75-3.23 \mathrm{~g} \cdot \mathrm{m}^{-2}\right)$. The dependence of air permeability on the basis weight is evident from Table 7 . With an increasing basis weight of membrane, the air permeability decreased, which is in good agreement with the literature regardless of the type of polymer [28]. Comparing the results with WCA from Table 2 shows increasing air permeability with decreasing the WCA. However, the dependence on the fiber diameter has not been confirmed in this study. This parameter seems to vary from case to case $[99,100]$. The dependence of air permeability on the amount of SF in the membrane is evident from Table 7. The higher the concentration of $\mathrm{SF}$, the better the air permeability.

Water vapor permeability (WVP) is a fundamental parameter in evaluating the comfort characteristics of membranes. The WVP in protecting clothing represents the ability of perspiration transfer what is also the case of filtration masks [101]. The results of water vapor permeability for the samples with a higher basis weight $\left(10-12 \mathrm{~g} \cdot \mathrm{m}^{-2}\right)$ was slightly higher than in the smaller basis weight $\left(1.75-3.23 \mathrm{~g} \cdot \mathrm{m}^{-2}\right)$ (Table 7). The WVP decreased in the range of $1-6 \%$. The most significant $6 \%$ decrease was recorded for r-PET, which was the fibrous mat with the largest basis weight and at the same time with the largest fiber diameters. It cannot be said that with increasing fiber diameter the WVP decreases, because permeability was measured and compared for the samples prepared in the same conditions and with similar structural characteristics (similar fibers diameter) from each basis weight and samples with different compositions. However, according to the available literature, WVP is only slightly dependent on fiber diameters, but the effect of basis weight has already been observed [102]. The dependence of WVP on the SF amount in the membrane is not evident. The changes are negligible, especially in the case of membranes with lower basis weight.

The expectations that the air and water vapor permeability was confirmed only in the case of air permeability. The higher amount of SF in the investigated membrane, the better air permeability.

\subsection{Antibacterial Activity}

Many authors described the antibacterial activity of silk fibroin. The published results, as well as opinions on this topic, seem clear. Silk is not considered a polymer with antibacterial activity $[89,103]$. On the other side, there have been published studies that have shown that the antibacterial activity of polymers in different forms is influenced by many factors related to its preparation, processing [104], possibly mixing with other polymers [50,105] or active molecules, drugs, and biocides [106-108].

In this study, the antibacterial activity of the electrospun r-PET, SF, and r-PSF6 was tested without any inhibiting agent by contact method, following the ISO22196:2011 against $S$. aureus as gram-positive and E. coli as gram-negative bacteria. In addition, the bacterial viability of both used strains was investigated after contact of $24 \mathrm{~h}$. Results are listed in Table 8.

Table 8. Antibacterial activity of the investigated electrospun mats. The values are listed in the form mean $\pm \mathrm{SD}$.

\begin{tabular}{|c|c|c|c|c|c|}
\hline $\begin{array}{c}\text { Tested } \\
\text { Microorganism }\end{array}$ & Sample & $\begin{array}{l}\text { The Number of Bacteria } \\
\text { Recovered at } 24 \mathrm{~h} \\
\left.\text { Contact Time (CFU. } \mathrm{cm}^{-2}\right)\end{array}$ & $\begin{array}{c}\text { Log of the Number of } \\
\text { Bacteria Recovered at } 24 \mathrm{~h} \\
\text { Contact Time }\left(\mathrm{CFU} \cdot \mathrm{cm}^{-2} \text { ) }\right.\end{array}$ & $\begin{array}{l}\text { Antimicrobial } \\
\text { Activity (R) }\end{array}$ & Reduction (\%) \\
\hline \multirow{3}{*}{$\begin{array}{l}\text { S. aureus } \\
\text { CCM } 3953\end{array}$} & r-PET & $390,000 \pm 18,000$ & $5.59 \pm 0.26$ & - & - \\
\hline & r-PSF6 & $21,000 \pm 1200$ & $4.26 \pm 0.24$ & $1.3 \pm 0.02$ & $94.62 \pm 6.6$ \\
\hline & $\mathrm{SF}$ & $350,000 \pm 16,400$ & $5.54 \pm 0.26$ & - & - \\
\hline \multirow{3}{*}{$\begin{array}{c}\text { E. coli } \\
\text { CCM } 3988\end{array}$} & r-PET & $550,000 \pm 25,000$ & $5.74 \pm 0.26$ & - & - \\
\hline & r-PSF6 & $30,000 \pm 1600$ & $4.48 \pm 0.24$ & $1.3 \pm 0.02$ & $94.55 \pm 6.4$ \\
\hline & SF & $480,000 \pm 21,300$ & $5.68 \pm 0.25$ & - & - \\
\hline
\end{tabular}


The numbers of recovered viable bacteria were established. The result of the antibacterial activity testing is the following already published studies [103].

Pure SF and r-PET are not antibacterial, and the bacterial films were forming on the membrane surface confirmed by SEM micrographs (Figure 9). Unlike published studies mentioned above and all the expectations, the experiment results showed that bacterial growth on the r-PSF6 was reduced for both tested strains. The viability of E.coli and S. aureus reduction for more than $94 \%$ was observed compared to r-PET and SF. The antimicrobial activity was calculated as $\mathrm{R}=1.3$ for $S$. aureus and $E$. coli. The explanation of this result could lie in the critical surface characteristics that are desirable for reducing bacterial binding and that are related to surface energy, roughness, and wettability [109]. It was shown by Yean et al. that the electrospun polystyrene surface with a WCA of $95^{\circ}$ gave the highest level of bacterial (E. coli) adhesion [110]. This corresponds with earlier research showing that a surface with WCA in the range $54-130^{\circ}$ had higher bacterial adhesion by promoting hydrophobic interaction between bacterial membrane and a solid surface [111]. In the case of this study, the antibacterial activity of the r-PSF6 could be explained by the higher wettability and lower WCA $43 \pm 4^{\circ}$.
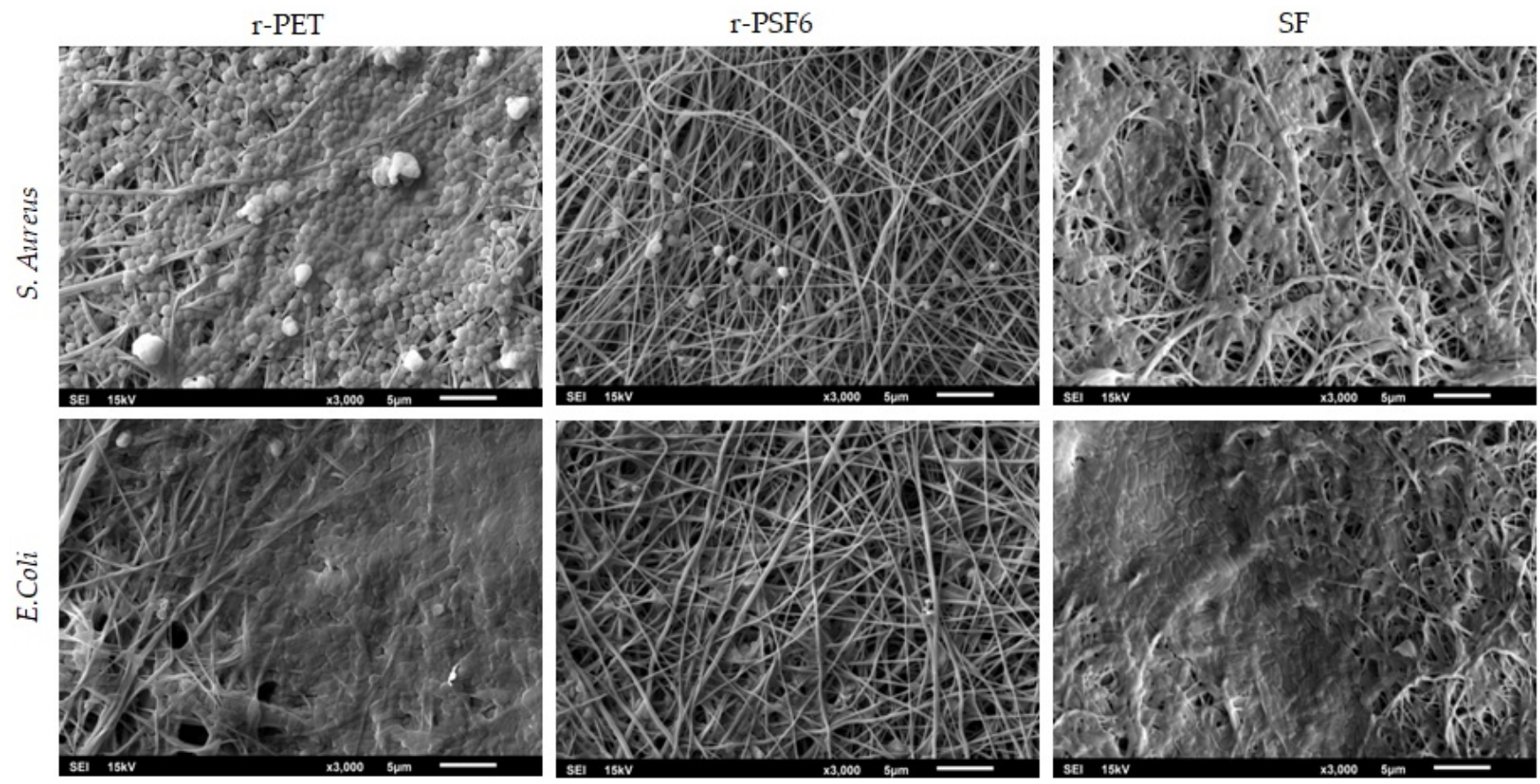

Figure 9. SEM micrographs of r-PET and r-PSF6 and SF show antibacterial efficiency against S. Aureus and E. Coli.

\subsection{Biocompatibility}

The biocompatibility of SF in many forms has already been studied by many researchers $[53,112,113]$. The majority of the amino acids in silk fibroin are glycine $(45.9 \%)$ and alanine $(30.3 \%)$, which show minimal chemical reactivity and give the SF unique features including biocompatibility, biodegradability, and host-implantation integration. Silk fibroin has been due to its biocompatibility studied in many applications such as tissue and nervous system regeneration [114,115], wound dressing [58,116], drug release systems [117], and sutures [118]. Herein, the cytotoxic effects of 24 and 48 h exposure of the investigated samples were evaluated in HaCaT cells by the MTT assay. HaCaT cells are the immortalized human keratinocytes, so the primary type of cells found in the outermost layer of the skin. In humans, they form $90 \%$ of epidermal skin cells $[119,120]$. They were selected due to the intended close skin contact with investigated materials. The results are summarized in Figure 10. As expected, the SF mats used in this study have proven to be biocompatible with the HaCaT cells used after 24 and $48 \mathrm{~h}$ incubation. 


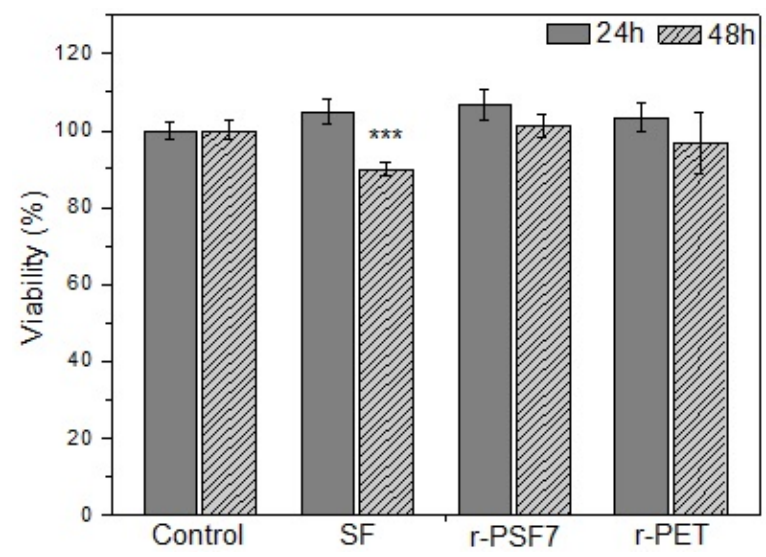

Figure 10. Biocompatibility of SF, r-PSF6, and r-PET mats after $24 \mathrm{~h}$ and $48 \mathrm{~h}$ incubation, respectively. Cell viability was determined by MTT assay. The results are presented as mean \pm SD of three independent experiments. The statistical significance is shown by asterisks $\left({ }^{* *} p<0.001\right)$.

As shown, r-PET and r-PSF6 had no cytotoxic effect on the HaCaT cells. Their viability slightly increased after $24 \mathrm{~h}$ of incubation, while after $48 \mathrm{~h}$ it decreased back to the control level. These results agree with the literature, which shows excellent biostability and biocompatibility of a Food and Drug Administration (FDA)-approved polymer PET [121].

\section{Conclusions}

Fibrous free-standing membranes were fabricated from the blend of mechanically stable recycled PET and silk fibroin extracted from the cocoon's silkworm Bombyx Mori. The membranes were prepared by electrospinning. Up until now, the membranes from the mixture of r-PET and SF were not published; therefore, the membranes were characterized by elemental techniques to investigate the basic features and subsequently were tested as aerosol filtration membranes to assess the suitability of these membranes for filtration. The mechanical, thermal, and chemical properties are affected by both present types of polymers.

The wettability of the r-PSFs composite membranes is modified distinctively with the increasing SF amount. The filtration efficiency $(\mathrm{FE})$ and quality factor $\left(\mathrm{Q}_{\mathrm{f}}\right)$, which represents filtration performance, were calculated from penetration through the membranes using DEHS aerosol particles ranging from $120 \mathrm{~nm}$ to $2.46 \mu \mathrm{m}$. The basis weight of the membranes influenced FE and $Q_{\mathrm{f}}$. Studied membranes with basis weight in the range of $10-12 \mathrm{~g} \cdot \mathrm{m}^{-2}$ exhibit FE $43-99 \%$ and $\mathrm{Q}_{\mathrm{f}} 0.012-0.024 \mathrm{~Pa}^{-1}$ and membranes with basis weight in the range $1.7-3.2 \mathrm{~g} \cdot \mathrm{m}^{-2}$ exhibit FE 39-96\% and $\mathrm{Q}_{\mathrm{f}} 0.018-0.039 \mathrm{~Pa}^{-1}$. The membrane r-PSF6 with the FE $90.23 \%$ was classified as FFP1 type according to the standard EN149. These results show the eventuality to use the investigated membrane r-PSF6 for personal protection. The other tested membranes showed too high a pressure drop. The effectivity of tested membranes r-PET, r-PSF3, and r-PSF6 were classified into the class E11, E10, and E10, in the case of lower basis weight and into the class H13, E12, and E12 in the case of higher basis weight according to EN1822. Antibacterial activity of r-PET, r-PSF6, and SF electrospun membranes has been tested. The air permeability was improving with the higher amount of SF in the composite. On the other hand, the addition of SF has no impact on the water vapor permeability. The viability of two strains of bacteria, S. aureus and E. coli, was reduced by around $95 \%$ after $24 \mathrm{~h}$ of contact time. The biocompatibility of investigated samples SF, r-PSF6, and r-PET have been proven. The studied samples were shown to have a non-cytotoxic effect after $48 \mathrm{~h}$ of incubation compared to control. Given the results presented, it can be concluded that the material would also be suitable for use in filtration application against bacteria, viruses, or other particles, even in nanoscale. 
Author Contributions: Conceptualization, A.O.Š. and A.E.A.; methodology, A.O.Š, K.M., J.F., M.B., J.H., A.O. and K.K.; software, A.O.Š., K.M., J.F., M.B., J.H., P.P. and A.O.; validation, A.O.Š. and A.E.A.; formal analysis, A.O.Š., K.M., J.F., M.B., J.H., K.K., P.P. and A.O.; investigation, A.O.Š., K.M., J.F., M.B. and K.K.; resources, A.O.Š., J.H., K.M., K.K. and A.E.A.; data curation, A.O.Š., P.P. and A.E.A.; writing—original draft preparation, A.O.Š., K.M., M.B. and A.E.A.; writing-review and editing, A.O.Š., P.P. and K.M.; visualization, A.O.Š. and A.E.A.; supervision, A.O.Š. and A.E.A.; project administration, A.O.Š. and A.E.A.; funding acquisition, A.O.Š. and A.E.A. All authors have read and agreed to the published version of the manuscript.

Funding: This research was funded by the Scientific Grant Agency of the Ministry of Education, Science, Research and Sport of the Slovak Republic under project VEGA no. 2/0135/19, and no. 2/0055/20. The present work was also supported by the Slovak Research and Development Agency under contracts no. APVV 18-0420 and no. APVV 19-0250 and through project SAS-MOST JRP 2019/07.

Institutional Review Board Statement: Not applicable.

Informed Consent Statement: Not applicable.

Acknowledgments: The authors would like to acknowledge networking support by the COST Action CA17107, CONTEXT, European Network to connect research and innovation efforts on advanced Smart Textiles.

Conflicts of Interest: The authors declare no conflict of interest.

\section{References}

1. Scudellari, M. How the Pandemic Might Play Out in 2021 an Beyond. News Feature. Available online: https://www.nature.com/ articles/d41586-020-02278-5 (accessed on 12 July 2021).

2. Statement on the Seventh Meeting of the International Health Regulations (2005) Emergency Committee Regarding the Coronavirus Deseade (COVID-19) Pandemic. Available online: https:/ /www.who.int/news/item/19-04-2021-statement-on-theseventh-meeting-of-the-international-health-regulations-(2005)-emergency-committee-regarding-the-coronavirus-disease(covid-19)-pandemic (accessed on 20 June 2021).

3. The facemask global value chain in the COVID-19 outbreak: Evidence and policy lessons. Available online: https: / / www.oecd.org/coronavirus / policy-responses/the-face-mask-global-value-chain-in-the-COVID-19-outbreak-evidenceand-policy-lessons-a4df866d/ (accessed on 23 July 2021).

4. Ivanoska-Dacikj, A.; Stachewicz, U. Smart textiles and wearable technologies-Opportunities offered in the fight against pandemics in relation to current COVID-19 state. Rev. Adv. Mater. Sci. 2020, 59, 487-505. [CrossRef]

5. Tebyetekerwa, M.; Xu, Z.; Yang, S.; Ramakrishna, S. Electrospun nanofibers-based face masks. Adv. Fiber Mater. 2020, 2, 161-166. [CrossRef]

6. Xu, J.; Xiao, X.; Zhang, W.; Xu, R.; Kim, S.C.; Cui, Y.; Howard, T.T.; Wu, E.; Cui, Y. Air-filtering masks for respiratory protection from $\mathrm{PM}_{2.5}$ and pandemic pathogens. OneEarth 2020, 3, 574-589. [CrossRef]

7. Leung, W.W.F.; Sun, Q. Charged PVDF multilayer nanofiber filter in filtering simulated airbone novel coronavirus (COVID-19) using ambient nano-aerosols. Sep. Purif. Technol. 2020, 245, 116887. [CrossRef]

8. Yin, X.; Yu, J.; Ding, B. Electrospun fibers for filtration. In Hanbook of Fibrous Materials, 1st ed.; Hu, J., Kumar, B., Lu, J., Eds.; Wiley-VCH: Weinheim, Germany, 2020; Volume 2, pp. 175-206. [CrossRef]

9. Rogina, A. Electrospinning process: Versatile preparation method for biodegradable and natural polymers and biocomposite systems applied in tissue engineering and drug delivery. Appl. Surf. Sci. 2014, 296, 221-230. [CrossRef]

10. Xue, J.; Wu, T.; Dai, Y.; Xia, Y. Electrospinning and electrospun nanofibers: Methods, materials, and applications. Chem. Rev. 2019, 119, 5298-5415. [CrossRef] [PubMed]

11. Zahmatkeshan, M.; Adel, M.; Bahrami, S.; Esmaeili, F.; Rezayat, A.M.; Saeedi, Y.; Mehravi, B.; Jameie, S.B.; Ashtari, K. Polymer based nanofibers: Preparation, Fabrication, and applications. In Hanbook of Nanofibers, 1st ed.; Barhoum, A., Bechalany, M., Makhlouf, A.S.H., Eds.; Springer: Cham, Switzerland, 2018; pp. 1-47. [CrossRef]

12. Aragón, J.; Costa, C.; Coelhoso, I.; Mendoza, G.; Aguilar-Ricardo, A.; Irusta, S. Electrospun asymmetric membranes for wound dressing applications. Mater. Sci. Eng. C 2019, 103, 109822. [CrossRef] [PubMed]

13. Locilento, D.A.; Mercante, L.A.; Andre, R.S.; Mattosi, L.H.C.; Luna, G.L.F.; Brassolatti, P.; Anibal, F.d.F.; Correa, D.S. Biocompatibile and biodegradable electrospun nanofibrous membranes loaded with grape seed extract for wound dressing application. J. Nanomater. 2019, 2472964. [CrossRef]

14. Bhattarai, D.P.; Aguilar, L.E.; Park, C.H.; Kim, C.S. A review on properties of natural and synthetic based electrospun fibrous materials for bone tissue engineering. Membranes 2018, 8, 62. [CrossRef]

15. Gabriel, L.P.; Rodrigues, A.A.; Macedo, M.; Jardini, A.L.; Filho, R.M. Electrospun polyurethane membranes for tissue engineering applications. Mater. Sci Eng. C 2017, 72, 113-117. [CrossRef] 
16. Gorrasi, G.; Longo, R.; Viscusi, G. Fabrication and characterization of electrospun membranes based on poly( $\varepsilon$-caprolactone), poly(3-hydroxybutyrate) and their blend for tunable drug delivery of curcumin. Polymers 2020, 12, 2239. [CrossRef]

17. Wu, J.; Zhang, Z.; Gu, J.; Zhou, W.; Liang, X.; Zhou, G.; Han, C.C.; Xu, S.; Liu, Y. Mechanism of a long-term controlled drug release system based on simple blended electrospun fibers. J. Control. Release 2020, 320, 337-346. [CrossRef] [PubMed]

18. Kweon, O.Y.; Lee, S.J.; Oh, J.H. Wearable high-performance pressure sensors based on three-dimensional electrospun conductive nanofibers. NPG Asia Mater. 2018, 10, 540-551. [CrossRef]

19. Aliheidari, N.; Aliahmad, N.; Agarwal, M.; Dalir, H. Electrospun nanofibers for label-free sensor application. Sensor 2019, 19, 3587. [CrossRef] [PubMed]

20. Shao, Z.; Jiang, J.; Wang, X.; Li, W.; Fang, L.; Zhen, G. Self-powered electrospun composite nanofiber membrane for highly efficient air filtration. Nanomaterials 2020, 10, 1706. [CrossRef] [PubMed]

21. Homaeigohar, S.; Elbahri, M. Nanocomposite electrospun nanofiber membranes for environmental remediation. Materials 2014, 7, 1017. [CrossRef] [PubMed]

22. Tong, Y.; Xu, Y.; Chen, D.; Xie, Y.; Chen, L.; Que, M.; Hou, Y. Deformamble and flexible electrospun nanofiber-supported crosslinked gel polymer electrolyte membranes for high safety lithium-ion batteries. RSC Adv. 2017, 7, 22728-22734. [CrossRef]

23. Arifeen, W.U.; Kim, M.; Ting, D.; Kurniawan, R.; Choi, J.; Kisoo, Y.; Ko, T.J. Hybrid thermal resistant electrospun polymer membrane as the separator of lithium ion batteries. Mater. Chem. Phys. 2020, 245, 122780. [CrossRef]

24. Thomas, M.; Rajiv, S. Dye-sensitized solar cells based on an electrospun polymer nanocomposite membrane as electrolyte. New J. Chem. 2019, 43, 4444-4454. [CrossRef]

25. Kaschuk, J.J.; Miettunen, K.; Borghei, M.; Frollini, E.; Rojas, O.J. Electrolyte membranes based on ultrafine fibers of acetylated cellulose for improved and long-lasting dye-sensitized solar cells. Cellulose 2019, 26, 6151-6163. [CrossRef]

26. Bonincontro, D.; Fraschetti, F.; Squarzoni, C.; Mazzocchetti, L.; Maccaferri, E.; Giorgini, L.; Zucchelli, A.; Gualandi, C.; Focarete, M.L.; Albonetti, S. Pd/Au based catalyst immobilization in polymeric nanofibrous membranes via electrospinning for the selective oxidation of 5-hydroxymethylfurfural. Processes 2020, 8, 45. [CrossRef]

27. Chan, S.; Jankovic, J.; Susac, D.; Saha, M.S.; Tam, M.; Yang, H.; Ko, F. Electrospun carbon nanofiber catalyst layers for polymer electrolyte membrane fuel cells: Fabrication and optimization. J. Mater. Sci. 2018, 53, 11633-11647. [CrossRef]

28. Gorji, M.; Jeddi, A.A.A.; Gharehaghaji, A.A. Fabrication and characterization of polyurethane electrospun nanofiber membranes for protective clothing applications. J. Appl. Polym. Sci. 2012, 125, 4135-4141. [CrossRef]

29. Yu, X.; Wu, X.; Si, Y.; Wang, X.; Yu, J.; Ding, B. Waterproof and breathable electrospun nanofibrous membranes. Macromol. Rapid Commun. 2019, 40, e1800931. [CrossRef] [PubMed]

30. Topuz, F.; Abdulhamid, M.A.; Nunes, S.P.; Szekely, G. Hierarchically porous electrospun nanofibrous mats produced from intrinsically microporous fluorinated polyimide for the removal of oils and non-polar solvents. Environ. Sci. Nano 2020, 7 , 1365-1372. [CrossRef]

31. Tian, Z.; Chee, T.S.; Zhang, X.; Lei, L.; Xiao, C. Novel bismuth-based electrospinning materials for highly efficient capture of radioiodine. Chem. Eng. J. 2021, 415, 128687. [CrossRef]

32. Topuz, F.; Holtzl, T.; Szekely, G. Scavenging organic micropollutants from water with nanofibrous hypercrosslinked cyclodextrin membranes derived from green resources. Chem. Eng. J. 2021, 419, 129443. [CrossRef]

33. Opálková Šišková, A.; Frajová, J.; Nosko, M. Recycling of poly(ethylene therephthalate) by electrospinning to enhanced the filtration efficiency. Mater. Lett. 2020, 278, 128426. [CrossRef]

34. Leung, W.W.F.; Sun, Q. Electrostatic charged nanofiber filter for filtering airbone novel coronavirus (COVID-19) and nano-aerosols. Sep. Purif. Technol. 2020, 250, 116886. [CrossRef]

35. Bortolassi, A.C.C.; Nagarajan, S.; de Araújo Lima, B.; Guerra, V.G.; Lopes Aguiar, M.; Huon, V.; Soussan, L.; Cornu, D.; Miele, P.; Bechelany, M. Efficient nanoparticles removal and bactericidal action of electrospun nanofibers membranes for air filtration. Mater. Sci. Eng. C 2019, 102, 718-729. [CrossRef]

36. Molnár, K.; Mészáros, L. The role of electrospun nanofibers in the fight against the COVID-19. Express Polym. Lett. 2020, 14, 605. [CrossRef]

37. Matulevicius, J.; Kliucininkas, L.; Prasauskas, T.; Buivydiene, D.; Martuzevicius, D. The comparative study of aerosol filtration by electrospun polyamide, polyvinyl acetate, polyacrylonitrile and cellulose acetate nanofiber media. J. Aerosol Sci. 2016, 92, 27-37. [CrossRef]

38. Min, K.; Kim, S.; Kim, S. Silk protein nanofibers for highly efficient, eco-friendly, optically translucent, and multifunctional air filters. Sci. Rep. 2018, 8, 9598. [CrossRef] [PubMed]

39. Li, H.; Wang, Z.; Zhang, H.; Pan, Z. Nanoporous PLA/(chitosan nanoparticle) composite fibrous membranes with excellent air filtration and antibacterial performance. Polymers 2018, 10, 1058. [CrossRef] [PubMed]

40. Zhang, Q.; Li, Q.; Young, T.M.; Harper, D.P.; Wang, S. A novel method for fabricating an electrospun poly(vinyl alcohol)/cellulose nanocrystals composite nanofibrous filter with low air resistance for high-efficiency filtration of particulate matter. ACS Sustain. Chem. Eng. 2019, 7, 8706-8714. [CrossRef]

41. Yun, K.M.; Hogan, C.J., Jr.; Matsubayashi, Y.; Kawabe, M.; Iskandar, F.; Okuyama, K. Nanoparticle filtration by electrospun polymer fibers. Chem. Eng. Sci. 2007, 62, 4751-5759. [CrossRef]

42. Pardo-Figuerez, M.; Chiva-Flor, A.; Figueroa-Lopez, K.; Prieto, C.; Lagaron, J.M. Antimicrobial nanofiber based filters for high filtration efficiency respirators. Nanomaterials 2021, 11, 900. [CrossRef] 
43. Victor, F.S.; Kugarajah, V.; Bangaru, M.; Ranjan, S.; Dharmalingam, S. Electrospun nanofibers of polyvinylidene fluoride incorporated with titanium nanotubes for purifying air with bacterial contamination. Environ. Sci. Pollut. Res. 2021, 28, 37520-37533. [CrossRef] [PubMed]

44. Bonfim, S.P.F.; Cruz, F.G.S.; Bretas, R.E.S.; Guerra, V.G.; Aguiar, M.L. A sustainable recycling alternative: Electrospun PETmembranes for air nanofiltration. Polymers 2021, 13, 1166. [CrossRef]

45. Zhu, M.; Han, J.; Wang, F.; Shao, W.; Xiong, R.; Zhang, Q.; Pan, H.; Yang, Y.; Samal, K.S.; Zhang, F.; et al. Electrospun nanofibers membranes for effective air filtration. Macromol. Mater. Eng. 2017, 302, 1600353. [CrossRef]

46. Bagheri, M.H.; Khalaji, I.; Azizi, A.; Loibl, R.T.; Basualdo, N.; Manzo, S.; Gorrepati, M.L.; Mehendale, S.; Mohr, C.; Schiffers, S.N. Filtration efficiency, breathability, and reusability of improvides materials for face masks. Aerosol Sci. Technol. 2021, 55, 817-827. [CrossRef]

47. Ryberg, M.; Laurent, A.; Hauschild, M. Mapping of Global Plastics Value Chain and Plastics Losses to the Environment (with a Particular Focus on Marine Environment); United Nations Environment Programme: Nairobi, Kenya, 2018; Available online: http:/ / wedocs.unep.org/bitstream/handle/20.500.11822/26745/mapping_plastics.pdf (accessed on 27 May 2021).

48. McKeen, L.W. Effect of radiation on the properties of polyester polymers. In The Effect of Radiation on Properties of Polymers; Plastic design Library; William Andrew: Norwich, NY, USA, 2020; Chapter 4; pp. 93-128. [CrossRef]

49. Begum, S.A.; Rane, A.V.; Kanny, K. Application of compatibilized polymer blends in automobile industry. In Compatibilization of Polymer Blends: Micro and Nano Scale Phase Morphologies, Interphase Characterization and Properties; Elsevier: Amsterdam, The Netherlands, 2020; Chapter 20; pp. 563-593. [CrossRef]

50. Caykara, T.; Sande, M.G.; Azoia, N.; Rodrigues, L.R.; Silva, C.J. Exploring the potential of polyethylene terephthalate in design of antibacterial surfaces. Med. Microbiol. Immunol. 2020, 209, 363-372. [CrossRef]

51. Sadeghi, B.; Marvafi, Y.; AliAkbari, R.; Kowsari, E.; Ajdari, F.B.; Ramakrishna, S. Recent studies on recycled PET fibers: Production and applications: A review. Mater. Circ. Econ. 2021, 3, 4. [CrossRef]

52. Grumezescu, A.M.; Stoica, A.E.; Dima-Balcescu, M.S.; Chircov, C.; Gharbia, S.; Balta, C.; Rosu, M.; Herman, H.; Holban, A.M.; Ficai, A.; et al. Electrospun polyethylene terephthalate nanofibers loaded with silver nanoparticles: Novel approach in antiinfective therapy. J. Clin. Med. 2019, 8, 1039. [CrossRef] [PubMed]

53. Nguyen, T.P.; Nguyen, Q.V.; Nhuyen, V.H.; Le, T.H.; Huynh, V.Q.N.; Vo, D.V.N.; Trinh, Q.T.; Kim, S.Y.; Le, Q.V. Silk fibroin-based bioamterials for biomedical applications: A review. Polymers 2019, 11, 1933. [CrossRef] [PubMed]

54. Calamak, S.; Erdogdu, C.; Ozalp, M.; Ulubayram, K. Silk fibroin based antibacterial bionanotextiles as wound dressing materials. Mater. Sci. Eng. C 2014, 43, 11-20. [CrossRef]

55. Amiraliyan, N.; Nouri, M.; Haghighat Kish, M. Structural characterization and mechanical properties of electrospun silk fibroin nanofiber mats. Polym. Sci. Ser. A 2010, 52, 407-412. [CrossRef]

56. Zhou, C.J.; Li, Y.; Yao, S.W.; He, J.H. Silkworm-based silk fibers by electrospinning. Res. Phys. 2019, 15, 102646. [CrossRef]

57. Shanmugam, V.; Babu, K.; Garrison, T.F.; Capezza, A.J.; Olsson, R.T.; Ramakrishna, S.; Hedenqvist, M.S.; Singha, S.; Bartoli, M.; Giorcelli, M.; et al. Potential natural polymer-based nanofibers for the development of facemasks in countering viral outbreaks. J. Appl. Polym. Sci. 2021, 138, 50658. [CrossRef]

58. Opálková Šišková, A.; Kozma, E.; Opálek, A.; Kroneková, Z.; Kleinová, A.; Nagy, Š.; Kronek, J.; Rydz, J.; Eckstein Andicsová, A. Diclofenac embedded in silk fibroin fibers as a drug delivery system. Materials 2020, 13, 3580. [CrossRef]

59. Bandeira, M.; Borges, V.; Gomes, J.P.; Duarte, A.; Jordao, J. Insight on Klebsiella pneumoniae biofilms assembled on different surfaces using phenotypic and genotypic approaches. Microorganisms 2017, 5, 16. [CrossRef] [PubMed]

60. Al-Attabi, E.; Dumée, L.F.; Kong, L.; Schütz, J.A.; Morsi, Y. High efficiency poly(acrylonitrile) electrospun nanofiber membranes for airborne nanomaterials filtration. Adv. Eng. Mater. 2017, 20, 1700572. [CrossRef]

61. Hes, L. Non-destructive determinantion of comfort parameters during marketing of functional garments and clothing. Indian J. Fibre Text. Res. 2008, 33, 239-245.

62. Razzaque, A.; Tesinova, P.; Hes, L.; Salacova, J.; Abid, H.A. Investigation on hydrostatic resistance and thermal performance of layeres waterproof breathable fabrics. Fibers Polym. 2017, 18, 1924-1930. [CrossRef]

63. ISO 22196. Measurement of Antibacterial Activity on Plastics and Other Non-Porous Surfaces; International Organization for Standardization: Geneva, Switzerland, 2011.

64. Prices for Most Recycled Plastics Continue to Rise. Available online: https://resource-recycling.com/recycling/2021/02/16 / prices-for-most-recycled-plastics-continue-to-rise/ (accessed on 23 June 2021).

65. Good Quality Carpet Yarn Spun Silk Pure White for Knitting and Weaving. Available online: www.alibaba.com/product-detail/ Good-quality-carpet-yarn-spun-silk_60711054364.html?spm=a2700.pc_countrysearch.main07.81.c05239bbQjN4SS (accessed on 23 June 2021).

66. Valeirinho, B.; Rei, M.F.; Lopes-Da-Silva, A. Solvent and concentration effects on the properties of electrospun poly(ethylene terephrthalate) nanofiber mats. J. Polym. Sci. B Polym. Phys. 2008, 45, 460-471. [CrossRef]

67. Guo, Y.; He, W.; Liu, J. Electrospinning polyethylene terephthalate/ $\mathrm{SiO}_{2}$ nanofiber composite needle felt for enhanced filtration performance. J. Appl. Polym. Sci. 2019, 137, 48282. [CrossRef]

68. D'Amato, A.R.; Bramson, M.T.K.; Puhl, D.L.; Johnson, J.; Corr, D.T.; Gilbert, R.J. Solvent retention in electrospun fibers affects scaffold mechanical properties. Electrospinning 2018, 2, 15-28. [CrossRef] 
69. Wang, H.; Zhang, Y.; Shao, H.; Hu, X. Electrospun ultra-fine silk fibroin fibers from aqueous solutions. J. Mater. Sci. 2005, 40, 5359-5363. [CrossRef]

70. Kishimoto, Y.; Kobashi, T.; Yamanaka, S.; Morikawa, H.; Tamada, Y. Comparisons between silk fibroin nonwoven electrospun fabric using aqueous and formic acid solutions. Int. J. Polym. Mater. Polym. Biomater. 2018, 57, 462-467. [CrossRef]

71. Chen, J.P.; Chen, S.H.; Lai, G.J. Preparation and characterization of biomimetic silk fibroin/chitosan composite nanofibers by electrospinning for osteoblasts culture. Nanoscale Res. Lett. 2012, 7, 170. [CrossRef] [PubMed]

72. Pavlova, E.; Nikishin, I.; Bogdanova, A.; Klinov, D.; Bagrov, D. The miscibility and spatial distribution of the components in electrospun polymer-protein mats. RSC. Adv. 2020, 10, 4672-4680. [CrossRef]

73. Herrero-Herrero, M.; Gómez-Tejedor, J.A.; Vallés-Lluch, A. Role of electrospinning parametrs on poly(lactic-co-glycolic acid) and poly(caprolactone-co-glycolic acid) membranes. Polymers 2021, 13, 695. [CrossRef] [PubMed]

74. Cheremisinoff, N. Industrial Solvents Handbook, 2nd ed.; Marcel Dekker Inc.: New York, NY, USA, 2008; pp. 51-53.

75. Angel, N.; Guo, L.; Yan, F.; Wang, H.; Kong, L. Effect of processing parameters on the electrospinning of cellulose acetate studied by response surface methodology. J. Agric. Food Res. 2020, 2, 100015. [CrossRef]

76. Abbas, J.A.; Said, I.A.; Mohamed, M.A.; Yasin, S.A.; Ali, Z.A.; Ahmed, H. Electrospinning of polyethylene terephthalate (PET) nanofibers: Optimization study using taguchi design of experiment. In IOP Conference Series: Materials Science and Engineering; IOP Publishing: Bristol, UK, 2018; Volume 454, p. 012130. [CrossRef]

77. Hashmi, M.; Ullah, S.; Saito, Y.; Haider, M.K.; Bie, X.; Wada, K.; Kim, I.S. Carboxymethyl cellulose (CMC) based electrospun composite nanofiber mats for food packaging. Polymers 2020, 13, 302. [CrossRef]

78. Tarus, B.; Fadel, N.; Al-Oufy, A.; El-Messinry, M. Efect of polymer concentration on the morphology and mechanical characteristics of electrospun cellulose acetate and poly(vinyl chloride) nanofiber mats. Alex. Eng. J. 2016, 55, 2975-2984. [CrossRef]

79. Mirtič, J.; Balažic, H.; Zupanič, Š.; Kristl, J. Effect of solution composition variables on tlectrospun alginate nanofibers: Response surface analysis. Polymers 2019, 11, 692. [CrossRef] [PubMed]

80. Karahalìloğlu, Z. Cell-compatible PHB/silk fibroin composite nanofiber mat for tissue engineering applications. Turk. J. Biol. 2017, 41, 503-513. [CrossRef]

81. Keirouz, A.; Zakharova, M.; Kwon, J.; Robert, C.; Koutsos, V.; Callanan, A.; Chen, X.; Fortunato, G.; Radacsi, N. High-throughput production of silk fibroin-based electrospun fibers as biomaterial for skin tissue engineering applications. Mater. Sci. Eng. C 2020, 112, 110939. [CrossRef]

82. Chen, F.; Ji, Z.; Qi, Q. Effect of pore size and layers on filtration performance of coalescing filters with different wettabilities. Sep. Purif. Technol. 2018, 201, 71-78. [CrossRef]

83. Fauzi, A.; Hapidin, D.A.; Munir, M.M.; Iskandar, F.; Khairurrijal, J. A superhydrophilic bilayer structure of a nylon 6 anofiber/cellulose membrane and its characterization as potential water filtration media. RSC Adv. 2020, 10, 17205-17216. [CrossRef]

84. Dou, H.; Yu, Z.; Zuo, B. Structure and antibacterial activity of silk fibroin/chitosan nanofibrous mats using an electrospinning technique. Adv. Mater. Res. 2011, 332, 967-972. [CrossRef]

85. Ovalle-Sánchez, A.A.; Elizondo-Martínez, P.; Pérez-Rodrígez, N.A.; Hernández-Fernández, E.; Sánchez-Anguiano, M.G. Degradation of poly(ethyleneterephthalate) waste to obtain oligomers uzing a zinc complex as catalyst. J. Chil. Chem. Soc. 2017, 62, 3741-3745. [CrossRef]

86. Dos Santos Pereira, A.P.; Prado da Silva, M.H.; Pereira Lima Júnior, É.; dos Santos Paula, A.; Tommasini, F.J. Processing and characterization of PET composites reinforced with geopolymer concrete waste. Mat. Res. 2017, 20, 411-420. [CrossRef]

87. Mohammadzadehmoghadam, S.; Dong, Y. Fabrication and characterization of electrospun silk fibroin/gelatin scaffolds crosslinked with glutaraldehyde vapor. Front. Mater. 2019, 6, 91. [CrossRef]

88. Kamalha, E.; Zheng, Y.; Zeng, Y. Analysis of the secondary crystalline structure of regenerated bombyx mori fibroin. Res. Rev. Biosci. 2013, 7, 76-83.

89. Calhoun, M.A.; Chowdhury, S.S.; Nelson, M.T.; Lannutti, J.L.; Dupaix, R.B.; Winter, J.O. Effect of electrospun fiber mat thickness and support method on cell morphology. Nanomaterials 2019, 9, 644. [CrossRef]

90. Gobin, A.S.; Froude, V.E.; Mathur, A.B. Structural and mechanical characteristics of silk fibroin and chitosan blend scaffolds for tissue regeneration. J. Biomed. Mater. Res. A 2005, 74A, 465-473. [CrossRef]

91. Mosnáčková, K.; Opálková Šišková, A.; Kleinová, A.; Danko, M.; Mosnáček, J. Properties and degradation of novel fully biodegradable PLA/PHB blends filled with keratin. Int. J. Mol. Sci. 2020, 21, 9678. [CrossRef]

92. Das, P.; Tiwari, P. Thermal degradation study of waste polyethylene terephthalate (PET) under inert and oxidative environments. Thermochim. Acta 2019, 679, 178340. [CrossRef]

93. Motta, A.; Fambri, L.; Migliaresi, C. Regenerated silk fibroin films: Thermal and dynamic mechanical analysis. Macromol. Chem. Phys. 2002, 203, 1658-1665. [CrossRef]

94. Liu, Y.; Yang, L.; Ma, C. Thermal analysis and kinetic study of native silk. J. Therm. Anal. Calorim. 2020, 139, 589-595. [CrossRef]

95. Tcharkhtchi, A.; Abbasnezhad, N.; Seydani, M.Z.; Zirak, N.; Farzaneh, S.; Shirinbayan, M. An overview of filtration efficiency through the masks: Mechanisms of the aerosol penetration. Bioact. Mater. 2021, 6, 106-122. [CrossRef]

96. EN1822-1. High Efficiency Air Filters (EPA, HEPA and ULPA)—Part 1: Classification, Performance Testing, Marking. Available online: https: / www.en-standard.eu/csn-en-1822-1-high-efficiency-air-filters-epa-hepa-and-ulpa-part-1-classificationperformance-testing-marking-3/ (accessed on 10 June 2021). 
97. EN 149:2001+A1:2009. Respiratory Protective Device-Filtering Half Masks to Protect against Particles-Requirements, Testing, Marking. Available online: https:/ / www.en-standard.eu/bs-en-149-2001-a1-2009-respiratory-protective-devices-filtering-halfmasks-to-protect-against-particles-requirements-testing-marking/ (accessed on 10 June 2021).

98. Liu, Y.Q.; Feng, J.W.; Zhang, C.C.; Teng, Y.; Liu, Z.; He, J.H. Air permeability of nanofiber membrane with hierarchical structure. Therm. Sci. 2018, 22, 1637-1643. [CrossRef]

99. Abuzade, R.A.; Zadhoush, A.; Gharehaghaji, A.A. Air permeability of electrospun polyacrylonitrile nanoweb. J Appl. Polym. Sci. 2012, 126, 232-243. [CrossRef]

100. McPherson, L. Correlation of Electrospun Polyvinylpyrrolidone Fiber Mat Thickness with Basis Weight, Fiber Diameter, Pore Size Distribution, and Air Permeability. Honor Research Project 662. 2018. Available online: http://ideaexchange.uakron.edu/ honors_research_projects / 662 (accessed on 30 May 2021).

101. Wang, R.; Liu, Y.; Li, B.; Hsiao, B.S.; Chu, B. Electrospun nanofibrous membranes for high flux microfiltration. J. Membr. Sci. 2012, 392, 167-174. [CrossRef]

102. Patel, S.U.; Manzo, G.M.; Patel, S.U.; Kulkarni, P.S.; Chase, G.G. Permeability of electrospun superhydrophobic nanofiber mats. J. Nanotechnol. 2012, 483976. [CrossRef]

103. Nadiger, V.G.; Shukla, S.R. Antibacterial properties of silk fabric treated with aloe vera and silver nanoparticles. J. Text. Inst. 2017, 108, 385-396. [CrossRef]

104. Kaur, J.; Rajkhowa, R.; Afrin, T.; Tsuzuki, T.; Wang, X. Facts and myths of antibacterial properties of silk. Biopolymers 2014, 101, 237-245. [CrossRef]

105. Yi, S.; Wu, Y.; Zhang, Y.; Zou, Y.; Dai, F.; Si, Y. Antibacterial activity of photoactive silk fibroin/cellulose acetate blend nanofibrous membranes against Escherichia coli. ACS Sustain. Chem. Eng. 2020, 8, 16775-16780. [CrossRef]

106. Ungur, G.; Hrůza, J. Modified nanofoibrous filters with durable antibacterial properties. Molecules 2021, 26, 1255. [CrossRef]

107. Calamak, S.; Alsoy, E.A.; Ertas, N.; Erdogdu, C.; Sagiroglu, M.; Ulubayram, K. Ag/silk fibroin nanofibers: Effect of fibroin morphology on $\mathrm{Ag}^{+}$release and antibacterial activity. Eur. Polym. J. 2015, 67, 99-112. [CrossRef]

108. Khan, A.U.R.; Huang, K.; Jinzhong, Z.; Zhu, T.; Morsi, Y.; Aldalbahi, A.; El-Newehy, M.; Yan, X.; Mo, X. Exploration of the antibacterial and wound healing potential of a PLAG/silk fibroin based electrospun membrane loaded with zinc oxide nanoparticles. J. Mater. Chem. B 2021, 9, 1452-1465. [CrossRef]

109. Kargar, M.; Wang, J.; Nain, A.S.; Behkam, B. Controlling bacterial adhesion to surface using topographical cues: A study of the interaction of Pseudomonas aeruginosa with nanofiber-textured surfaces. Soft Matter 2012, 8, 10254-10259. [CrossRef]

110. Yuan, Y.; Hays, M.P.; Hardwidge, P.R.; Kim, J. Surface characteristics influencing bacterial adhesion to polymeric substrates. RSC Adv. 2017, 7, 14254. [CrossRef]

111. Dou, X.; Zhang, C.; Feng, C.; Jiang, L. Bioinspired hierarchical surface structures with tunable wettability for regulating bacteria adhesion. ACS Nano 2015, 9, 10664-10672. [CrossRef]

112. Kaushik, S.; Thungon, P.D.; Goswami, P. Silk fibroin: An emerging biocompatible material for application of enzymes and whole cells in bioelectronics and bioanalytical sciences. ACS Biomater. Sci. Eng. 2020, 6, 4337-4355. [CrossRef]

113. Xu, S.; Yan, X.; Zhao, Y.; Wang, W.; Yang, Y. In vitro biocompatibility of electrospun silk fibroin mats with Schwann cells. J. Appl. Polym. Sci. 2010, 119, 3490-3494. [CrossRef]

114. Yonesi, M.; Garcia-Nieto, M.; Guinea, G.V.; Panetsos, F.; Perez-Rigueiro, J.; Gonzalez-Nieto, D. Silk Fibroin: An ancient material for repairing the injured nervous systems. Pharmaceutics 2021, 13, 429. [CrossRef]

115. Mejia-Sauza, M.L.; Moncada, M.E.; Ossa-Orozco, C.P. Characterization of electrospun silk fibroin scaffolds for bone tissue engineering: A review. TecnoLógicas 2020, 23, 228-246.

116. Hodgkinson, T.; Yuan, X.F.; Bayat, A. Electrospun silk fibroin fiber diameter influences in vitro dermal fibroblast behavior and promotes healing of ex vivo wound models. J. Tiss. Eng. 2014, 5, 1-13. [CrossRef]

117. Hong, H.; Zhang, D.; Lin, S.; Han, F.; Wang, K.; Jiang, D.; Wu, J.; Mo, X.; Wang, H. Green electrospun silk fibroin nanofibers loaded with cationic ethosomes for transdermal drug delivery. Chem. Res. Chin. Univ. 2021, 37, 488-495. [CrossRef]

118. Choudhury, A.J.; Gogoi, D.; Chutia, J.; Kandimalla, R.; Kalita, S.; Kotoky, J.; Chaudhari, Y.B.; Khan, M.R.; Kalita, K. Controlled antibiotic-releasing antheraea assama silk fibroin suture for infection prevention and fast wound healing. Surgery 2016, 159, 539-547. [CrossRef] [PubMed]

119. Choi, M.; Lee, C. Immortalization of primary keratinocytes and its application to skin research. Biomol. Ther. 2015, 23, 391-399. [CrossRef]

120. Ogawa, Y.; Kinoshita, M.; Shimada, S.; Kawamura, T. Zinc in keratinocytes and langerhans cells: Relevance to the epidermal homeostasis. J. Immunol. Res. 2018, 2018, 5404093. [CrossRef]

121. Jafari, S.; Salekdeh, S.S.H.; Solouk, A.; Yousefzadeh, M. Electrospun polyethylene terephthalate (PET) nanofibrous conduit for biomedical application. Polym. Adv. Technol. 2019, 31, 284-296. [CrossRef] 